

\section{DISCLAIMER}

This report was prepared as an account of work sponsored by an agency of the United States Government. Neither the United States Government nor any agency Thereof, nor any of their employees, makes any warranty, express or implied, or assumes any legal liability or responsibility for the accuracy, completeness, or usefulness of any information, apparatus, product, or process disclosed, or represents that its use would not infringe privately owned rights. Reference herein to any specific commercial product, process, or service by trade name, trademark, manufacturer, or otherwise does not necessarily constitute or imply its endorsement, recommendation, or favoring by the United States Government or any agency thereof. The views and opinions of authors expressed herein do not necessarily state or reflect those of the United States Government or any agency thereof. 


\section{DISCLAIMER}

Portions of this document may be illegible in electronic image products. Images are produced from the best available original document. 
NOTICE

This report was prepared as an account of work sponsored by the United States Government. Neither the United States nor the United States Department of Energy, nor any of their employees, makes any warranty, express or implied, or assumes any legal liability or responsibility for the accuracy, completeness, or usefulness of any information, apparatus, product, or process disclosed, or represents that its use would not infringe privately owned rights. Reference herein to any specific commercial product, process, or service by trade name, mark, manufacturer, or otherwise, does not necessarily constitute or imply its endorsement, recommendation, or favoring by the United States Government or any agency thereof. The views and opinions of authors expressed herein do not necessarily state or reflect those of the United States Government or any agency thereof.

Avallable from:

Nat1onal Teehnical information Service (N1LS)

U.S. Department of Commerce

5285 Port Royal Road

Springfield, Virginia 22161

Price:

Printed Copy:

$\$ 7.00$ 


\title{
Energy Implications of an Aging Population
}

\author{
August 1980
}

Prepared for:

U.S. Department of Energy

Office of Energy Research

Satellite Power System Project Division

Washington, D.C. 20545

Prepared by:

School of Engineering and Applied Science

The George Washington University

Washington, D.C. 20052

Under Contract No. AC01-79ER10041

DOE/NASA

Satellite Power System

Concept Development and

Evaluation program 
This study provides various demographic, medical, and economic information relative to energy usage on a segment of the population, the elderly, which is growing in absolute numbers and relative population percentage. This growth is expected to continue well into the twentyfirst century.

The U. S. aging population numbered 3.1 million in 1900, and by 1977 it had climbed to 23.5 million. It can be stated with reasonable certainty that this figure will rise to 31 million in the year 2000 and 43 million in the year 2020. These figures, corresponding to more than $10 \%$ of our population, are by no means insignificant.

As our fossil-fuel reserves are being depleted and the cost of energy mounts, it becomes apparent that the elderly will become increasingly vulnerable to the energy crisis, primarily because of their physical tendency to infirmity, their economic and social situation, and their susceptibility to psychological depression. In some sense, it can be argued that the problem of the aged is little different from that of the rest of the population. However, there are certain subtleties that suggest that the energy problems faced by the elderly are not too different from those of the poor and the disabled.

This "white paper" concentrates, therefore, on those aspects of. aging and the nation's energy problem which are not usually related in our everyday consideration of these as separable problems. It seeks to identify the peculiar energy problems of the aged and to consider alternatives in the solution of these problems in light of modern technology.

The aging constitute an important constituency. This constituency has energy requirements similar to the rest of the population, but it also has distinct differences. For instance, in considering economics, the elderly are more likely to be disadvantaged and more likely to have. to make the decision: heat versus food, medical care, or quality of life concerns. Fifteen percent of the total elderly are classed as living in poverty, with those not living with families as bearing the heaviest burden, particularly those in the rural South. Our social structure presently takes account of economic disadvantages in the population. The structure is now and will in the future be called upon increasingly 
to include energy factors, such as a heating subsidy in this economic equation.

While elderly are being challenged economically, their medical problem is compounded by their energy needs and their relative lack of tolerance to energy deficiency. This manifests itself principally in their vulnerability to abnormal temperature environments. Thus, they tend to require a more even temperature, inferring specific energy demand, for which they may not have the requisite financial assets.

Perhaps the most interesting aspect of the elderly consideration is the question of demographics of the "over 65" segment of our population. In addition to the most striking statistic mentioned above, that of gross numbers and percentages of elderly in the United States, nther numbers representing the demographics of the elderly are impressive. Some of these nuances should prove interesting to energy planners. Recent figures show almost $50 \%$ more "over 65 " females than males. The elderly are not concentrated in the Sun Belt although there is a discernible trend of movement to the South and West. Percentage increases of elderly population from 1970-77 was more than double for the South and West over the Northeast and North Central: While the elderly exhibit a low propensity to move, they seem to move locally or to the South and West when they do move.

Other demographic factors which may bear significantly on energy usage patterns of the elderly are:

- Urban/Non-Urban Mix;

- Living Arrangements; and

- Housing and Heating

These factors are all significant in the conclusions which may be drawn relative to the predominance of fossil fuel heating systems in use in homes of the elderly, the inferred insulation condition of this older housing and the efficiency of this arrangement as a total system.

The elderly are a unique constituency sharing certain characteristics of the poor and handicapped. They are a reasonably articulate group. which will exert well-informed pressure for what they consider to be the needs of their group and the nation as a whole. They are extremely concerned about the energy problem largely because of their medical and economic vulnerability. The combination of a weakening 
physical constitution; lower than average income; generally older, less energy efficient housing; living mostly in the city and, to a significant extent, nearly alone or completely alone leads to the conclusion that needs of this substantial, growing segment of our society must be afforded consideration as the social assessments of our alternative energy systems are proposed and developed. 


\section{TABLE OF CONTENTS}

Page

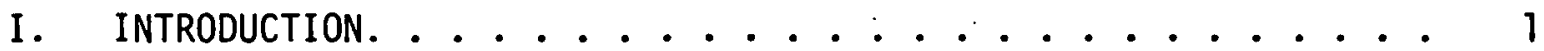

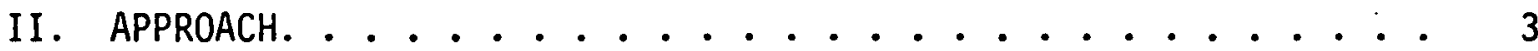

A. Methodology .................. 3

B. Definition of the Aged. ............. 4

C. Problems and Exemplar Issues. ........... 6

1. Data.................... 6

2. Needs :................... 6

3. Type of Energy System .............. 6

4. System Maintenance. ............ . 7

5. Cost of Alternate Systems............ 7

6. Housing Design. ............. 7

7. Transportation. . . . . . . . . . 7

8. Appliance Compatibility . . . . . . . . . 8

9. Communications. . ............. 8

10. Solar Constraints .............. 8

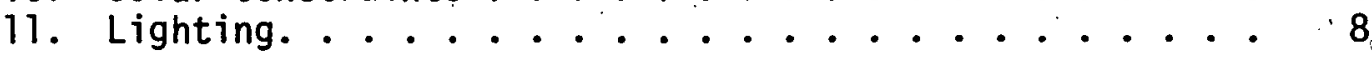

III. PROFILE OF THE OLDER POPULATION ................... 9

A. General ..................... 9

B. Size and Composition.............. 10

C. Distribution Patterns ................. 15

D. Social Characteristics. . . . . . . . . . 26

E. Economic Status . . . . . . . . . . . 28

F. Housing Characteristics ............ 36

1. Characteristics of Housing. ......... 36

2. Hous ing-Related Expenses. . . . . . . . 49

IV. FACTORS ASSOCIATED WITH ENERGY NEEDS. AND ENERGY USAGE OF

THE AGED. ......................... 53

A. Demographic Background. . . . . . . . . . . 53

B. Income. .................. 54

C. Biological and Physical Factors ........... 55

D. Housing ................... 55

E. Miscellaneous Factors ............. 56

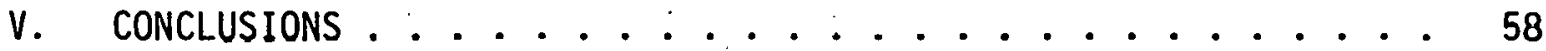

REFERENCES ..................... 60 


\section{$\underline{\text { LIST OF TABLES }}$}

Page

Table 1: Age Structure of the Population 65 Years of Age and 01der, by Age and Sex, and Sex Ratioa: 1950-1977 . . . . 11

Table 2: Absolute Size and Proportion of the Population Age 65 and Older in Each Geographic Division and State, 1977 . . . 13

Table 3: Percentage Distribution of the Population Age 65 and 01 der and Perrent. Increase in the Absolute Number of Persons Aged 65 and Older, by Region and Division: $1970-1977$. . . . . . . . . . 16 16

Table 4: Percentage of the Poputation Age 65 and OTder in Urban Areas by Region: 1960-1970 .......... 20

Table 5: Percentage Distribution of Marital Status for Persons Age 65 and 01der, by Sex and Age: $1970 \ldots 23$

Table 6: Percentage Distribution of Living Arrangements for Persons Age 65 and 07der, by Sex and Age: 1970 . . . . 25

Table 7: Percentage Distribution of Total Money Income for Persons Age 65 and 01der, by Family Status: 1976. . . . 29

Table 8: Poverty Rates for the Population Age 65 and 01der, by Region, Metropolitan - Nonmetropolitan Place of Residence and Family Status: 1975. .......... 31

Table 9: Percentage of Persons Agc 65 and 01der Receiving Income From Selected Sources by Family Status: $1976 \ldots 34$

Table 10: Percentage Distribution of Selected Housing Characteristics of Households with Head Age 65 or 01der, by Tenure and Metropolitan Status: 1973..................... 37

Table 11: Percentage Distribution of Types of Heating Equipment in Households with Head Age 65 or 01der, by Tenure and Metropolitan Status: 1973.

Table 12: Percentage Distribution of Types of Heating Fuel in Households with Head Age 65 or 01der, by Tenure and Metropolitan Status: 1973.

Table 13: Percentage Distribution of Types of Cooking Fuel in Households with Head Age 65 or 01der, by Tenure and Metropolitan Status: 1973............. 45 


\section{LIST OF FIGURES}

Page

Figure 1: Elderly Age Structure by. Sex. . . . . . . . . 12

Figure 2: Percentage of Elderly by Geographic Areas, 1977 . . . 17

Figure 3: Increase in Elderly, 1970-77. . . . . . . . 18

Figure 4: Proportion of Urban Elderly to Total Elderly,

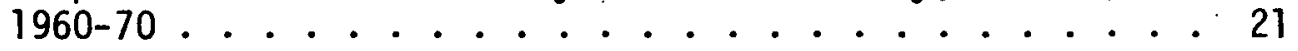

Figure 5: Living Arrangements, Persons 65 and Over, 1970. . . . 24

Figure 6: Elderly Income, 1976. ............. 30

Figure 7: Elderly Poor, Percent of Total Below Poverty Level, 1975................... 32

Figure 8: Elderly. Income Sources, 1976. . . . . . . . 35

Figure 9: Age of Elderly Housing, 1973.......... 39

Figure 10: Elderly Heating Equipment, 1973 . . . . . . . . 42 $\because$

Figure 11: Elderly Fuel Use by Type, 1973... . . . . . . . . 46

Figure 12: Elderly Cooking Fuel by Type, 1973. . . . . . . . . 47

Figure 13: Fuel Costs for 60 and Over, 1973, 1976....... 50 


\section{INTRODUCTION}

It is apparent that within the next half-century the world, in general, and the U.S., in particular, will be required to change the pattern of energy use. Changes will be made in generation, storage and distribution systems, and even in total and relative amounts expended for various end uses.

These changes could rival, or even exceed, the revolutionary changes already made by societies from wood to coal to oil to nuclear. The nuclear transition presently is underway, but serious questions have been raised lately relative to its safety and overall validity. The transition to nuclear power has raised the public consciousness and, therefore, the government sensitivity to the social costs and benefits related to large-scale systems. Naturally, each of the various constituencies may view these costs and benefits in a different light, one which is closely. attuned to their unique situation. The enlightened sponsor of a largescale program seeks to inform itself concerning the interests of the several social and political constituencies which stand to influence the supported program, either positively or negatively, sometimes many years and many millions of dollars after inception.

This study provides various demographic, medical and economic information relative to energy usage on a segment of the population, the elderly, which is growing in absolute numbers and relative population percentage. This growth is expected to continue well into the twentyfirst century.

Although it would appear at first that age does not play a role in how people utilize energy, upon further examination, it becomes evident that energy demand differs between age groups. Because the aged generally live on fixed and limited incomes, some of these problems are economic. There are also medical aspects, particularly those related to temperature. and lighting, since the aged are particularly susceptible to variations in these.

This "white paper" concentrates, therefore, on certain aspects of aging and the nation's energy problem, which are not usually related in our everday consideration of these as separable problems. It seeks to 
identify the peculiar energy problems of the aged and to consider some alternatives in solving these problems.

The Satellite Power System Project Office is seeking to understand and reflect the interests of this substantial constituency in the Concept Development and Evaluation Program, for it is recognized that energy al ternatives must consider the needs of the elderly which represent difficult although not insurmountable problems. 


\section{APPROACH}

As our non-renewable energy sources become depleted and as energy costs rise, a shift to alternate energy sources becomes mandatory. Many new sources have been suggested and are subjects. of research. In considering these sources, two points can be made:

- The alternate energy forms will most. likely not be cheaper. to install than present fuels. However, the costs are likely to remain relatively stable. Indeed, innumerable life-cycle cost analyses indicate that many systems using alternate energy will pay back their investments in less than 10 years.

- The new sources of energy will take time to develop to the commercialization stage. Depending on the form of energy, and in the absence of crash programs, the time-delay may be anywhere from several years to several decades.

Although both observations should be of interest to the general populace, they are of particular concern to the so-called aged who generally. live on fixed and limited incomes. In addition, the aged have energy demands different from those of the affluent and the robust young.

\section{A. Methodology}

Accordingly, a study was undertaken to examine the energy needs of the aged. Under a grant from the U.S. Department of Energy, ${ }^{*}$ The George Washington University, Office of Energy Programs, was asked to provide a report delineating the impact(s) of on-site and centralized power systems on the aged population.

The study was conducted at the School of Engineering and Applied Science of The George Washington University by the Office of Energy Programs.

At the outset of the study, a number of social indicators was identified -- twenty-five to be exact. Examples of these indicators are health, education, employment, taxes, and cultural factors. Each distributed system was evaluated according to these indicators. This evaluation was used as a point of departure for the remainder of the study.

* U.S. DOE Grant. Number EG-77-G-01-4040; Technology Assessment of Solar Energy Studies. 
An interdisciplinary group of engineers and social scientists was then convened in an informal workshop to focus on the problem areas and to delineate the boundaries.

Next, on the basis of the aforementioned findings, a series of background papers was commissioned. These include the following: the aged;

- A position paper on the physical and psychological needs of

- A position paper on the demography and housing of the aged;

- A position paper on the economics of the aged; and

- A position paper on the sociology of the aged.

Finally, all these inputs were synthesized into the present "white paper."

The informal workshop referred to above was convened to make a preliminary analysis of the problem, to define the issues that must be considered, and to identify the most competent authors of the commissioned papers that would constitute the report. Attendees at this workshop included Dr. A.B. Cambel and Mr. G.A. Heffernan, both of the Office of Energy Programs, The George Washington University; Dr. E. West, Administration on Aging, Department of Health, Education and Welfare; Ms. 0. Gooden, Private Citizen, former editor of United Mine Workers Welfare and Retirement rund; Mr. R. M111s, Adrlinislralur, Friends House Nursing Home; Dr. V. Portnoi, Geriatric Division, The George Washington University; and Mr. and Mrs. R. Reams, Private Citizens, Gray Panthers. Although the energy alternatives are numerous, the workshop placed emphasis on specitic solar energy forms, e.g.., sular hot water heating, solar heating and cooling, wood burning, wind energy, photovoltaics, and Satellite Power Systems.

The demographic data were developed by Ms. Carol. DeVita of Georgetown University who is duly acknowledged as a co-author of this paper.

The draft paper was subjected to Peer Review, and the authors are grateful for the critiques of Mr. Charles Bloomquist, Ms. Opal Gooden, Ms.. R. Joyce Harman, Mr. Fred A. Koomanoff, Ms. El izabeth Markham, and Dr. Herbert Pollack.

B. Definition of the Aged

There is no good definition of the term "aged.". One dictionary defines aged as follows: (1) "old; on in years; (2) of pertaining to 
or characteristic of old age." 1 But this is at best a circular definition because, in the true sense, aging is a continuous process (we all grow older from the day of conception), and different persons age at different rates.

The medical profession's characterization of the aging process as "a time scale in the human life scale" is also not adequate. ${ }^{2}$ Age means more than the number of years torn off a calendar; one person aged 70 can be well preserved biologically and have the physiological characteristics of someone aged 55. Chronological age, in fact, is poorly correlated with the biological status of an individual. For a person who has highrisk conditions for survival (e.g. smoking habits, high blood pressure, high cholesterol level), the biological ages would be greater than the chronological. Conversely, it can be less than the chronological age if positive health influences, such as moderate exercise habits, positive occupational environment, a family. history of long-lived ancestors, etc., prevail. Biologically, the aging process of an organism starts at conception and continues until death. Life experience during the adult period (and in certain cases during childhood) determines to a great extent one's fate in old age. There is nothing correlative between one's. chronological: age and one's being aged.

For example, Congressman Claude Pepper, who is over 80, pursues an active political life. At age 83, actor-comedian George Burns is still spritely, leads a vigorous life, and has just starred in a hi.t. movie. Other persons lose their energy well before these ages.

Therefore, one does not suddenly get old or aged by passing a given age. The aging process has many components, so that any study of the aged is compounded by a confusion that arises in defining those whom society calls "old" or. "the elderly." The aging process is a biopsycho-socio-economic process, not merely a chronological one, and this concept is the cornerstone for an understanding of the complexity of the multiple problems of and concerning the aged.

I William Morris (ed.), The American Heritage Dictionary of the English Language (New York: American Heritage Publishing Company, 1969), p. 24.

2 V. Portnoi, "Overview of Aging as a Bio-psycho-social Process," Unpublished (January 1979). 
However, even though some persons retire early, while others work actively into their seventies and eighties, most statistics of the aged are based on age 65 . In order to be able to make valid comparisons, we shall use this latter figure.

\section{Problems and Exemplar Issues}

In the course of our study, we tried to identify the more important problems that the aged population might face as users of future energy systems in general. Preliminary discussions suggest that the problems could be serious, unless they are anticipated and unless solutions are designed. As a starting point, we list some of the issues that must be considered (the order does not indicate priorities).

1. Data

Demographic projections of the aged by region must be obtained, and the statistical data must be analyzed. At first sight, this may seem simple, but it is actually complicated because age per se, as we have shown, is not an indication of physical state or mental activity. We need to determine the demands -- physical, economic, cultural -- which use of solar-energy technology will make upon its users and to correlate these with the needs -- and abilities -- of the aged.

\section{Needs}

An atlas of the needs of the aged energy user must be developed. For instance, is it factual that, as people get older, they require a higher room temperature in winter? (In a recent television documentary, it was stated that elderly persons should not keep their thermostats below $65^{\circ} \mathrm{F}$.) If this is so, solar space heating facilities must be properly designed so that the temperatures and the storage system are adequate. Conversely, do the elderly. suffer from heat prostration in summer? Many aged migrate to warm climates where space cooling is desirable. Will solar space cooling be within the reaches of their income?

\section{Type of Energy System}

The aged, like everybody else, need electricity. How is this need to be met -- by photovoltaics, large centralized systems, or perhaps even wind-energy conversion systems? Can people who are infirm and poor deal with the maintenance when no infrastructure exists for such systems? 


\section{System Maintenance}

If the aged use solar energy equipment, how will they be repaired? Can repairs be made in a timely enough fashion that no health- or comfort-threatening experiences result? The potential of chills resulting in pneumonia and of falls due to a failed lighting systems are both particularly serious for the aged. What happens if a major centralized power system fails, and there is no decentralized back-up?

\section{Cost of Alternate Systems}

On low or fixed incomes, how can aged citizens afford to purchase an on-site solar facility or to tie in to what might well be an expensive centralized system that supplies electricity to their residences? If they live in nursing homes, which may be poorly financed, will these institutions be able to obtain the funds for solar energy systems? Will individuals be assessed higher taxes due to installed systems on their own dwellings?

\section{Housing Design}

Frequently, the aged migrate to retirement communities such as are found in Arizona, California and Florida. Often, they obtain housing in retirement communities built by developers. Do these developers provide enough flexibility in their architecture so that requirements for reliable solar energy systems are incorporated when houses are designed for the convenience of the aged? Conversely, if houses using solar energy systems are built especially for the comfort of the aged, what resale value will they have?

\section{Transportation}

Personal mobility is a valuable social and economic factor for the aged, as well as for the remainder of society. As physical mobility declines in later years, the need for assistance from transportation systems becomes acute if social isolation and resulting depression are to be avoided.

For the type of local traveling many aged do, electric cars are often ideal. Can these have suitable battery chargers that operate from alternate sources? On the other hand, the aged also travel long distances to visit their children and grandchildren. Many use cars and/or mobile homes. Will they be able to afford the ever increasing cost of vehicles and gasoline? 


\section{Appliance Compatibility}

In their homes, the aged must have convenience appliances such as toasters, dish washers, waste-disposal units, etc. Frequently, these are obsolete and consume large amounts of energy. Can these be operated with solar energy systems and at what cost? Can future centralized systems substitute for, or interface with, existing electric utility systems?

. Communications

Within the next few decades, electronic communications are likely to expand. Some of these are ideal for the aged, e.g., electronic grocery- and catalogue-ordering, reading library books from cathode-raytube display panels, etc. Can such equipments be made compatible with solar electric energy? Many aged while away their hours by watching television. Would photovoltaics, wind electric generators or Solar Satellite Power System transmission systems cause objectionable interference with television signals?

\section{Solar Constraints}

Many aged people live in small houses, mobile homes or trailers. Do these have enough area to accommodate the right-size photovoltaic and collector panel areas to heat and cool the home adequately? Can transmission lines from SSPS be properly installed? Are such homes close enough to SSPS rectenna sites to minimize transmission costs?

\section{Lighting}

Because older people generally have lessened visual acuity, sufficient lighting for work, hobbies, and reading is essential $\because$ Reliable energy systems that are not prone to brownouts and blackouts are required.

It is not the purpose of this study to answer the aforementioned issues directly because this is being cone by other researchers. What this study addresses is the unique and particular energy problems of the aged so that these concerns may be studied knowledgeably. 


\section{PROFILE OF. THE OLDER POPULATION}

\section{A. General}

Populations, or societies, also "age." Whereas human aging is sequential and inevitable, population aging is not. The age of a population is determined with respect to its age structure, i.e., the relative distribution of members in the population by age. A population is said to be "old" when a high proportion of its members is concentrated in the age group 65 years of age and over. At the time of the 1970-1971 Census, the German Democratic Republic was the "oldest" nation in the world with 15.6 percent of its population 65 years of age or older; Mali, with but 1.5 percent of its population in the older ages., was the youngest. ${ }^{3}$ Worldwide, the median percent aged 65 and over was 5:0. The United States, with 9.9 percent elderiy in 1970, was considered a mature, but rapidly aging, population. Since that time, the proportion of older persons in our population has increased to 10.9, placing the United States among the ranks of the aged countries in the world. This suggests that, in planning its energy future, the United States must take into consideration the specific problems that face its aged population.

The aging of the U.S. population has brought multiple social and economic consequences. The considerable attention accorded the financing of the Social Security System in recent years is but one example. Other issues of debate include such diverse problems as the desirability of mandatory retirement, the rising cost of health care, the need for safe and adequate housing, and the distribution and consumption of our natural resources. Demographic. trends are, in a sense, an appropriate backdrop for the study of social problems and can aid in the formulation of public policy. By understanding the demographic composition of the population, the policymaker can better plan to meet the needs of society's individuals.

This section will focus on the demographic changes in our population that have occurred over time, as well as on the socio-demographic and economic characteristics of the older age groups, per se. For this discussion, the older population shall be defined as persons age 65 and

3 Based on a survey of 80 countries which provide age-specific census-type data. 
over (despite the limitations previously mentioned). Although this is a popular benchmark for defining old age, it does not imply that the older population is a homogeneous group. The socio-economic and demographic differences that are seen in younger age groups persist and accumulate at the older ages. Human aging is continuous, and the effects of previous life-cycle experiences and decisions will continue to be important in the later years. For example, an older person who remained childless will not have the possibility of personal care or assistance from his or her adult child later in life. Similarly, persons with a life history of low or poverty-level incomes will not have accumulated resources or asscts for use in old age. The cumulation of life-cycle events will be reflected in the diverse social and economic characteristics of the older population and will be important to the formulation and implementation of any public policy program.

\section{B. Size and Composition}

During the twentieth century, the population of the United States has "aged." 4 Demographically, there has been an increase not only in the absolute size of the older population but also an increase in the proportion of elderly in the total population. In 1900, 3.1 million persons were age 65 or older, representing 4.1 percent of the population. By 1960, this number had grown to 16.7 million and by 1977 to 23.5 million. Proportionally, the elderly comprised 9.2 percent of the population in 1960 and 10.9 percent in 1977.

Since 1960, the older population has grown faster than the population as a whole, with the aged segment increasing by 21 percent compared with a 13 percent increase in the total population. Although the recent growth rate of the older population is impressive, it is considerably less than that of the 1950's when the elderly recorded a similar substantial increase. Projections made by the Bureau of the Census anlicipate a continued growth in the size of the older population but at a slower rate than is currently observed. The slow-growth pattern will persist until the year 2020. At that time, the baby-boom cohorts will begin to

4 The United Nations considers any country that has seven percent or more of its population concentrated in the older ages to be "aged." 
Table -1.

Age Structure of the Population 65 Years of Age and Older, by Age and Sex, and Sex Rat10 : 1950-1977 (Numbers in Thousands)

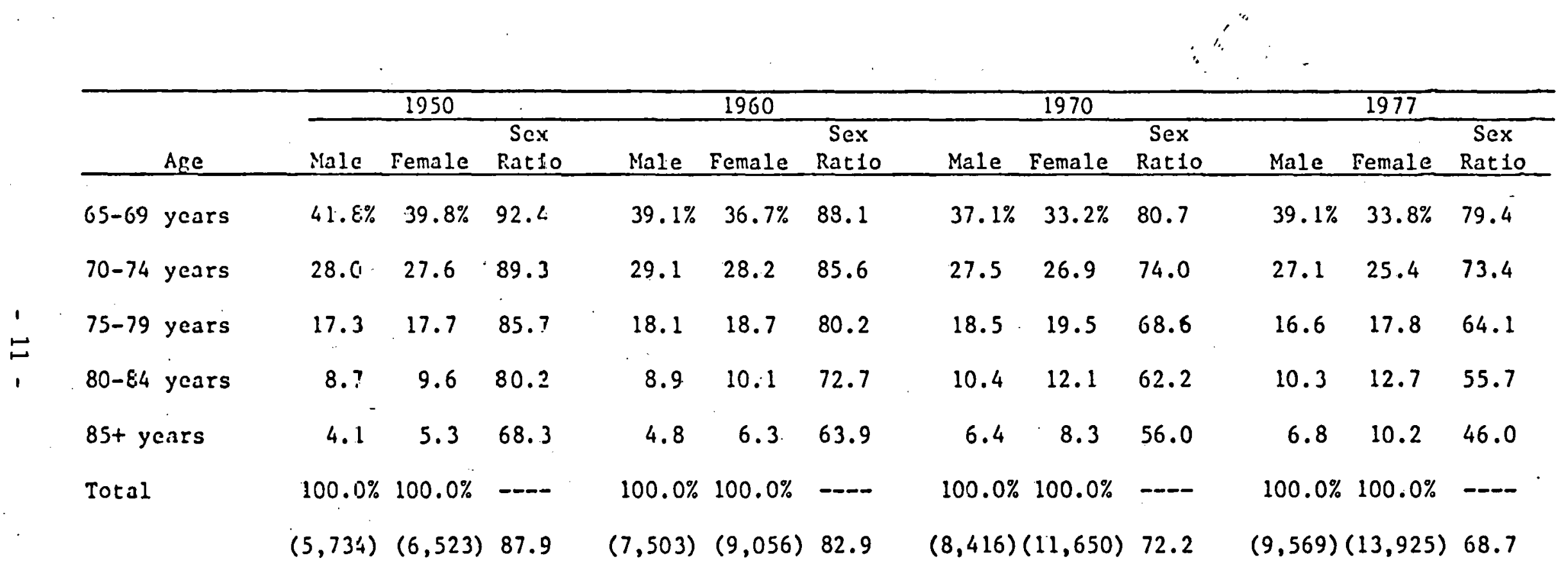

-Sex ratios reflect the number of males per 100 females.

Sources: Unfted States Bureau of the Census. Current Population Reports. Serles P-25, No. 721, Issued April, 1978. "Estimates of the Population of the United States by Age, Sex, and Race: 1970 to 1977." Table 2.

United States Bureau of the Census. 1970 Census of the Population. "General Population Characteristics, Unlted States Summary PC(1)-Bl." Table 52.

Unfted States Bureau, of the Census. 1960 Census of the Population. "Detafled Characteristics, United States Summary." Table 158. 
FIGURE 1: ELDERLY AGE STRUCTURE BY SEX

1977

1

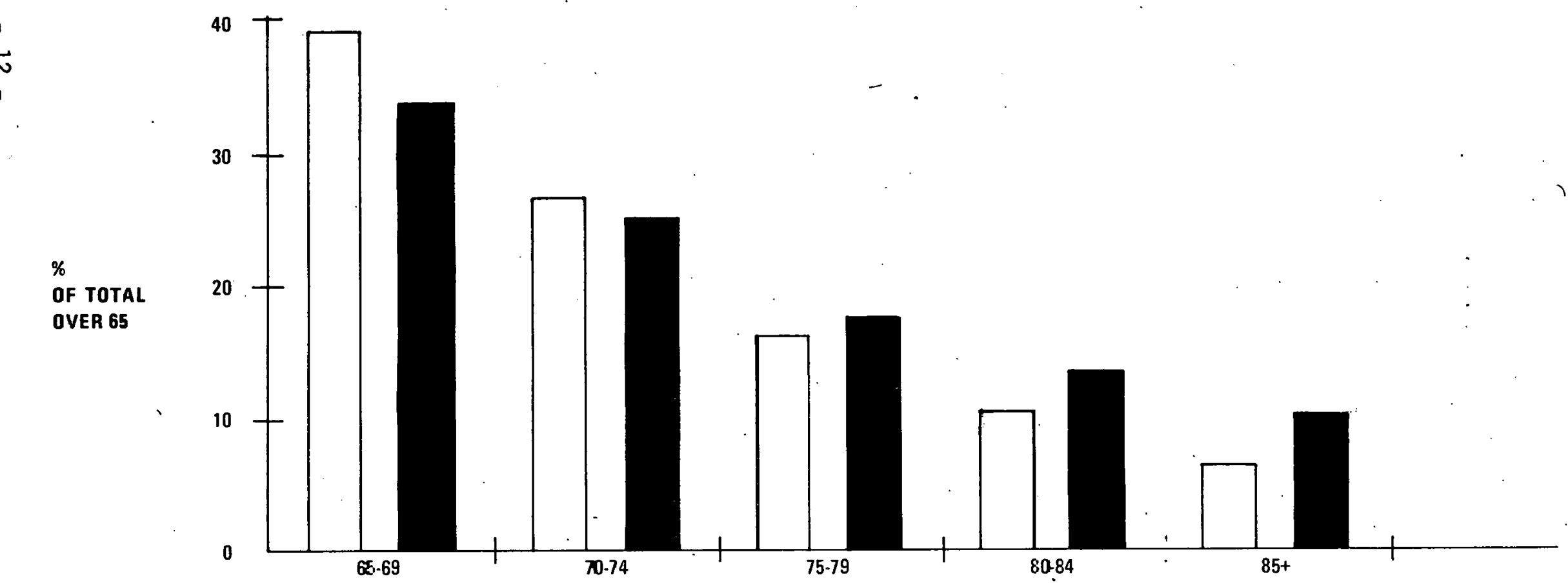

MALES $\quad 9,569,000$

FEMALES $13,925,000$ 
Table 2.

Absolute Size and Proportion of the Population Age 65 and Older

in Each Geographic Division and State, 1977

(Numbers in Thousands)

\begin{tabular}{|c|c|c|c|}
\hline Division and State & Population Age $65+$ & Total Population & $\%$ Elderly \\
\hline United States, total & 23,494 & 216,332 & 10.9 \\
\hline New England & 1,421 & 12,242 & 11.6 \\
\hline Maine & 130 & 1,085 & 12.0 \\
\hline New Hampshire & 93 & 849 & 11.0 \\
\hline Vermont & 54 & 483 & 11.2 \\
\hline Massachusetts & 687 & 5,782 & 11.9 \\
\hline Rhode Island & 118 & 935 & 12.6 \\
\hline Connecticut & 340 & 3,108 & 10.9 \\
\hline Middle Atlantic & 4,321 & 37,038 & 11.7 \\
\hline New York & 2,082 & 17,924 & 11.6 \\
\hline New Jersey & 808 & 7,329 & 11.0 \\
\hline Pennsylvania & 1,432 & 11,785 & 12.2 \\
\hline East North Central & 4,240 & 41,057 & 10.3 \\
\hline Ohio & 1,110 & 10,701 & 10.4 \\
\hline Indiana & 554 & 5,330 & 10.4 \\
\hline Illinois & 1,194 & 11,245 & 10.6 \\
\hline Michigan & 850 & 9,129 & 9.3 \\
\hline Wisconsin & 534 & 4,651 & 11.5 \\
\hline West North Central & 2,107 & 16,884 & 12.5 \\
\hline Mlinnesota & 454 & 3,975 & 11.4 \\
\hline Iowa & 374 & 2,879 & 13.0 \\
\hline Missouri & 622 & 4,801 & 13.0 \\
\hline North Dakota & 77 & 653 & 11.8 \\
\hline South Dakota & 88 & 689 & 12.8 \\
\hline Nebraska & 199 & 1,561 & 12.7 \\
\hline Kansas & 293 & 2,326 & 12.6 \\
\hline South Atlantic & 3,834 & 34,305 & 11.2 \\
\hline Delaware & 53 & 582 & 9.1 \\
\hline Maryland & 359 & 4,139 & 3.7 \\
\hline District of Columbia & 71 & 690 & 10.3 \\
\hline Virginia & 454 & 5,135 & 8.8 \\
\hline West Virginia & 219 & 1,859 & 11.8 \\
\hline North Carolina & 530 & 5,525 & 9.6 \\
\hline South Carolina & 247 & 2,876 & 8.6 \\
\hline Georgia & 456 & 5,048 & 9.0 \\
\hline Florida & 1,444 & 8,452 & 17.1 \\
\hline
\end{tabular}


Table 2 continued.

\begin{tabular}{|c|c|c|c|c|c|}
\hline Division and State & & Population Age 65+ & Total & Population & $\%$ Elderlv \\
\hline $\begin{array}{l}\text { East South Central } \\
\text { Kentucky } \\
\text { Tennessee } \\
\text { Alabama } \\
\text { Mississippi }\end{array}$ & . & $\begin{array}{r}1,510 \\
382 \\
465 \\
398 \\
266\end{array}$ & . & $\begin{array}{r}13,837 \\
3,453 \\
4,299 \\
3,690 \\
2,389\end{array}$ & $\begin{array}{l}10.9 \\
11.0 \\
10.8 \\
10.8 \\
11.1\end{array}$ \\
\hline $\begin{array}{l}\text { West South Central } \\
\text { Arkansas } \\
\text { Louisiana } \\
\text { Oklahoma } \\
\text { Texas }\end{array}$ & 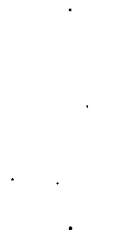 & $\begin{array}{r}2,225 \\
285 \\
363 \\
349 \\
1,228\end{array}$ & & $\begin{array}{r}21,707 \\
2,144 \\
3,921 \\
2,811 \\
12,830\end{array}$ & $\begin{array}{r}10.3 \\
13.3 \\
9.3 \\
12.4 \\
9.6\end{array}$ \\
\hline $\begin{array}{l}\text { Mountain } \\
\text { Montana } \\
\text { Idaho } \\
\text { Wyoming } \\
\text { Colorado } \\
\text { New Mlexico } \\
\text { Arizona } \\
\text { Utah } \\
\text { Nevada }\end{array}$ & $\begin{array}{l}\vdots \\
\vdots \\
\vdots \\
\vdots\end{array}$ & $\begin{array}{r}918 \\
79 \\
84 \\
35 \\
224 \\
98 \\
250 \\
98 \\
51\end{array}$ & & $\begin{array}{r}10,031 \\
761 \\
857 \\
406 \\
2,619 \\
1,190 \\
2,296 \\
1,268 \\
633\end{array}$ & $\begin{array}{r}9.2 \\
10.4 \\
9.8 \\
8.6 \\
8.6 \\
8.2 \\
10.9 \\
7.7 \\
8.1\end{array}$ \\
\hline $\begin{array}{l}\text { Pacific } \\
\text { Washington } \\
\text { Oregon } \\
\text { California } \\
\text { Alaska } \\
\text { Hawaii }\end{array}$ & & $\begin{array}{r}2,919 \\
386 \\
274 \\
2,185 \\
9 \\
63\end{array}$ & . & $\begin{array}{r}29,232 \\
3,638 \\
2,376 \\
21,896 \\
407 \\
895\end{array}$ & $\begin{array}{r}10.0 \\
10.6 \\
11.5 \\
10.0 \\
2.2 \\
7.0\end{array}$ \\
\hline
\end{tabular}

Source: United States Bureau of the Census. Current Population Reports. Series P-25, No. 734. Issued November, 1978. "Estimates of the Population of States, by Age: July 1, 1971 to 1977." Tablo 1. 
reach old age, and rapid growth among the older segment of the population will reappear. ${ }^{5}$

Differences in the size and rate of increase in the older population are observed by both age and sex. Table 1, summarized in Figure 1, illustrates the recent age structure of the population age 65 and older. From a study of these data over the past thirty years, it is noted that there has been a concentration of growth at the very oldest age groups; in 1950, there were only 12.8 percent of elderly males and 14.9 percent of females who were over 80: This percentage had increased to 17.1 and 22.9, respectively, in 1977. Concurrently, the proportion of males and females at the youngest age group (i.e., age 65-69) had diminished slightly.

Second, there has been a widening gap between the number of elderly males and the number of elderly females. The increasing imbalance between the sexes is reflected in the sex ratio -- a measure indicating the number of males per 100 females in the population. Sex differentials in mortality have favored the survivorship of women and have caused an excess of elderly females to elderly males. As Table 1 indicates, the sex ratio declines as men and women progress through the older ages, but $i$ t has also declined substantially over time. In 1950 there were approximately 88 men per 100 women in the population. This measurement fell to 69 males by 1977. Similar reductions can be seen at every age group and across time. There is little evidence to assume a reversal of this trend.

\section{Distribution Patterns}

The geographical distribution of the older population can be measured in several ways. Table 2 represents one way; it indicates the number of elderly in each state vis-a-vis the total population of the state in 1977. Although large numbers of elderly can be found in the more heavily populated areas, such as the states of New York and California, the proportion of elderly in most states hovers around the national average of 10.9 percent. Only Florida exhibits an extremely high concentration

5 J.S. Siegel, "Demographic Aspects of Aging and the 0lder Population in the United States," Current Population Reports, Series P-23, No. 59 (Washington, DC: U.S. Government Printing Office, 1976). 
Table 3.

Percentage Distribution of the Population Age 65 and Older and Percent Increase in the Absolute Number of Persons Aged 65 and Older, by Region and Division: 1970 and 1977 (Numbers in Thousands)

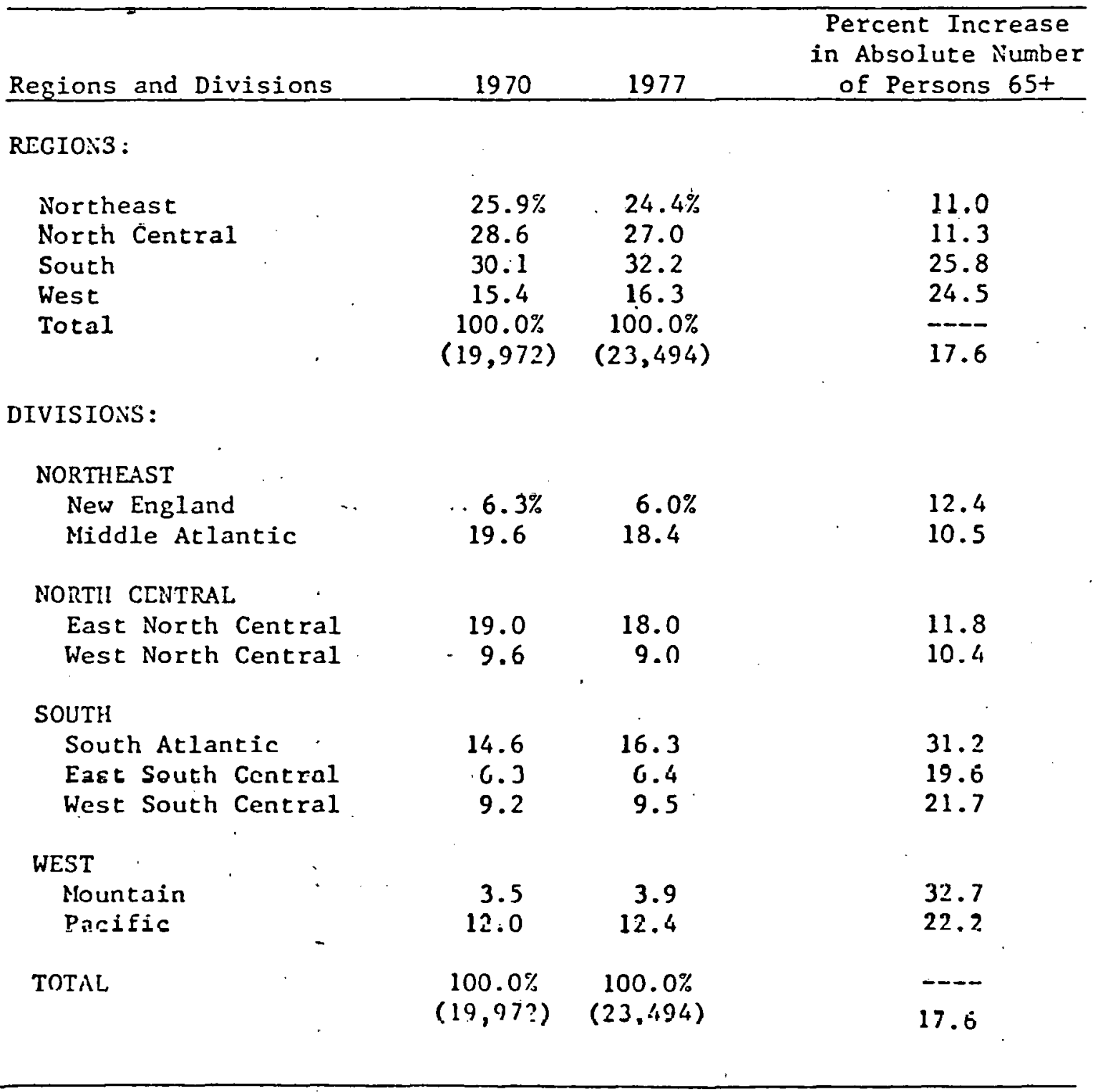

Source: United States Bureau of the Census. Current Population Reports. Series $\mathrm{P}=25$, Nu. 734. Issued November, 1978. "Estimates of the Population of States, by Age: July 1, 1971 to 1977." Tables 1 and 3. 
FIGURE 2: PERCENTAGES OF ELDERLY

BY GEOGRAPHIC AREAS

1977

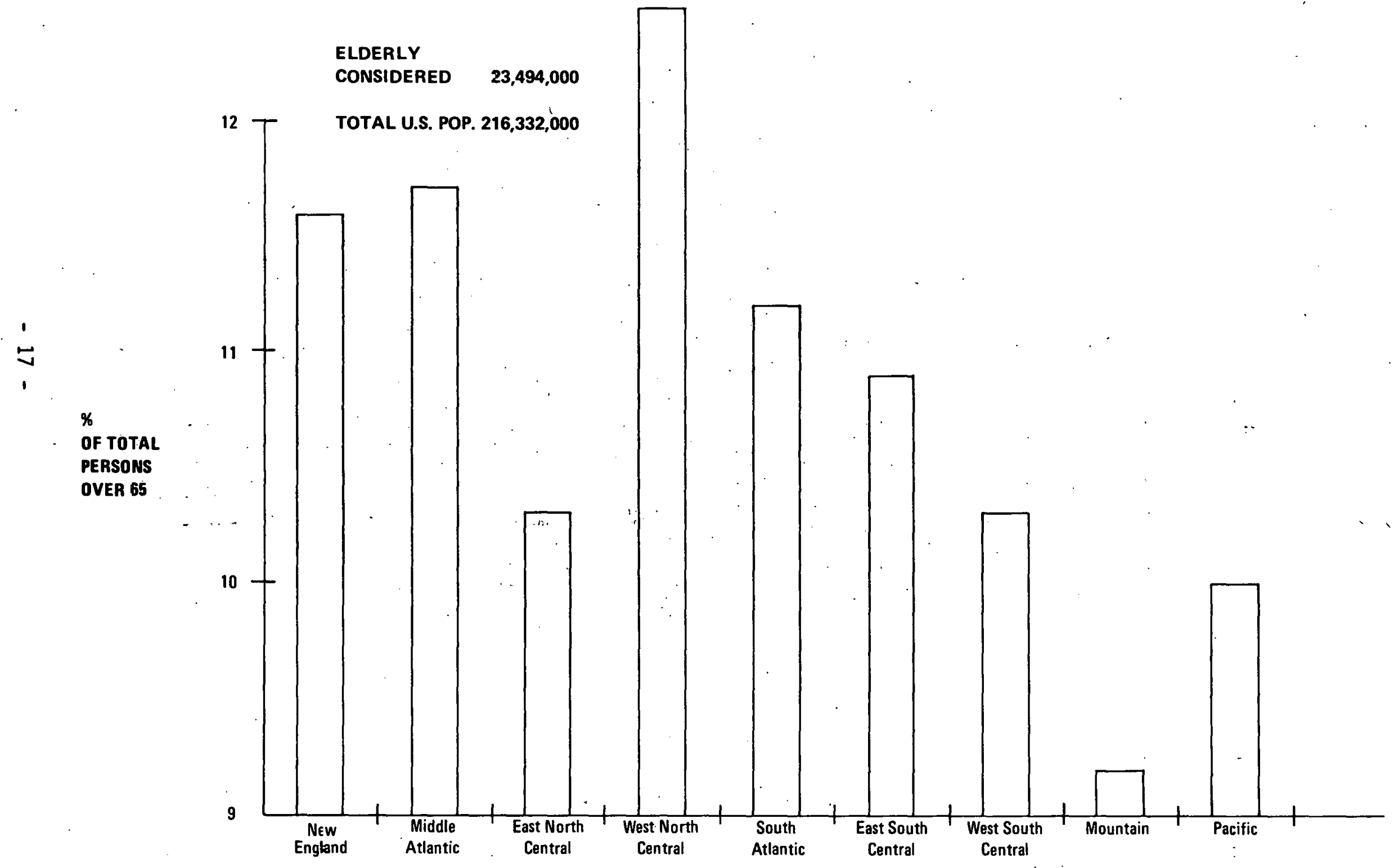


FIGURE 3: INCREASE IN ELDERLY

1970-77

ABSOLUTE NOS

$65+$

1970

1977

$19,972,000 \quad 23,494,000$ $\infty$

30

IN ABSOLUTE

NUMBERS OF

PERSONS

.65+

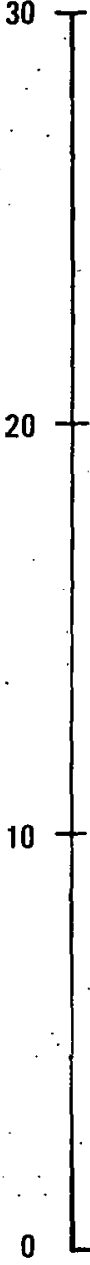


of elderly, with 17.1 percent of its population age 65 and over. In contrast, Alaska, Hawai $i$ and Utah fall substantially below the national norm.

Perhaps a clearer indicator of the geographical distribution of the elderly can be seen in Table 3 and Figure 3. Looking at the four geographic regions of the country, the figure indicates an increase in the number of elderly in all regions between: 1970 and 1977 . The South and the West experienced a growth rate more than double that of the Northeast and North Central regions. Changes in the percentage distribution of elderly by region, however, were less dramatic. Although the South and West increased their share of the older population, the changes were minor. The South and the West are we11-located for decentralized solar energy. By the same token, the homes in these areas are relatively new and are mainly heated and cooled by electricity. The older population is increasing in these areas by in-migration and will probably occupy new housing in most cases. These housing structures would lend themselves handily to decentralized solar energy such as heating and cooling and photovoltaics, because it would not be required to retrofit older residences with new systems.

The data in Table 3 and Figures 2 and 3 show that the elderly are disproportionately represented in the more highly urbanized and industrialized sections of the country. Nearly two of every five older persons live in the Middle Atlantic and eastern North Central states. Only a small portion of the older population resides in New England, eastern South Central, and Mountain states. The fact that many older persons live in the Middle. Atlantic and eastern North Central states suggests that centralized energy systems may be very worthwhile in these regions. New homes could be all-electric, and retrofitting is easiest with electricity. of course, the worth of any plan depends greatly on who pays for what. It may be just as economical to provide "energy stamps" for conventional energy as to subsidize solar heating or solar hot water heating, either of which may appear to be particularly attractive for the elderly. On the other hand, as Table 3 indicates, the South has the greatest occupancy of the elderly, namely 32.2 percent in 1977; this suggests that, so far as the aged are concerned, there is good potential for matching the 
Table 4 Percentage of the Population Age 65 and older in IIrban Areas by Region: 1960 - 1970

\begin{tabular}{lcccc}
\multicolumn{5}{c}{ (Numbers in thousands) } \\
\cline { 2 - 5 } Region & $\begin{array}{c}\text { 1960 } \\
\text { Total Elderly } \\
\text { Population }\end{array}$ & $\begin{array}{c}\text { \% Urban } \\
\text { Urban }\end{array}$ & $\begin{array}{c}\text { Total Elderly } \\
\text { Population }\end{array}$ \\
\hline Northeast & 81.2 & 4,498 & 82.6 & 5,199 \\
North Central & 66.2 & 5,078 & 69.3 & 5,727 \\
South & 56.8 & 4,582 & 63.0 & 6,043 \\
West & 79.5 & 2,401 & 82.8 & 3,096 \\
Total & 69.6 & 16,559 & 72.9 & 20,065 \\
\hline
\end{tabular}

Source: United States Bureau of the Census. 1970 Census of the Population "General Population Characteristics, United. States Summary, PC (1)-B1". Table 57.

United States Bureau of the Census. 1960 Census of the Population. "General Population Characteristics, United States Summary." Table 52 . 
FIGURE 4: PROPORTION OF URBAN ELDERLY TO TOTAL ELDERLY

1960-70

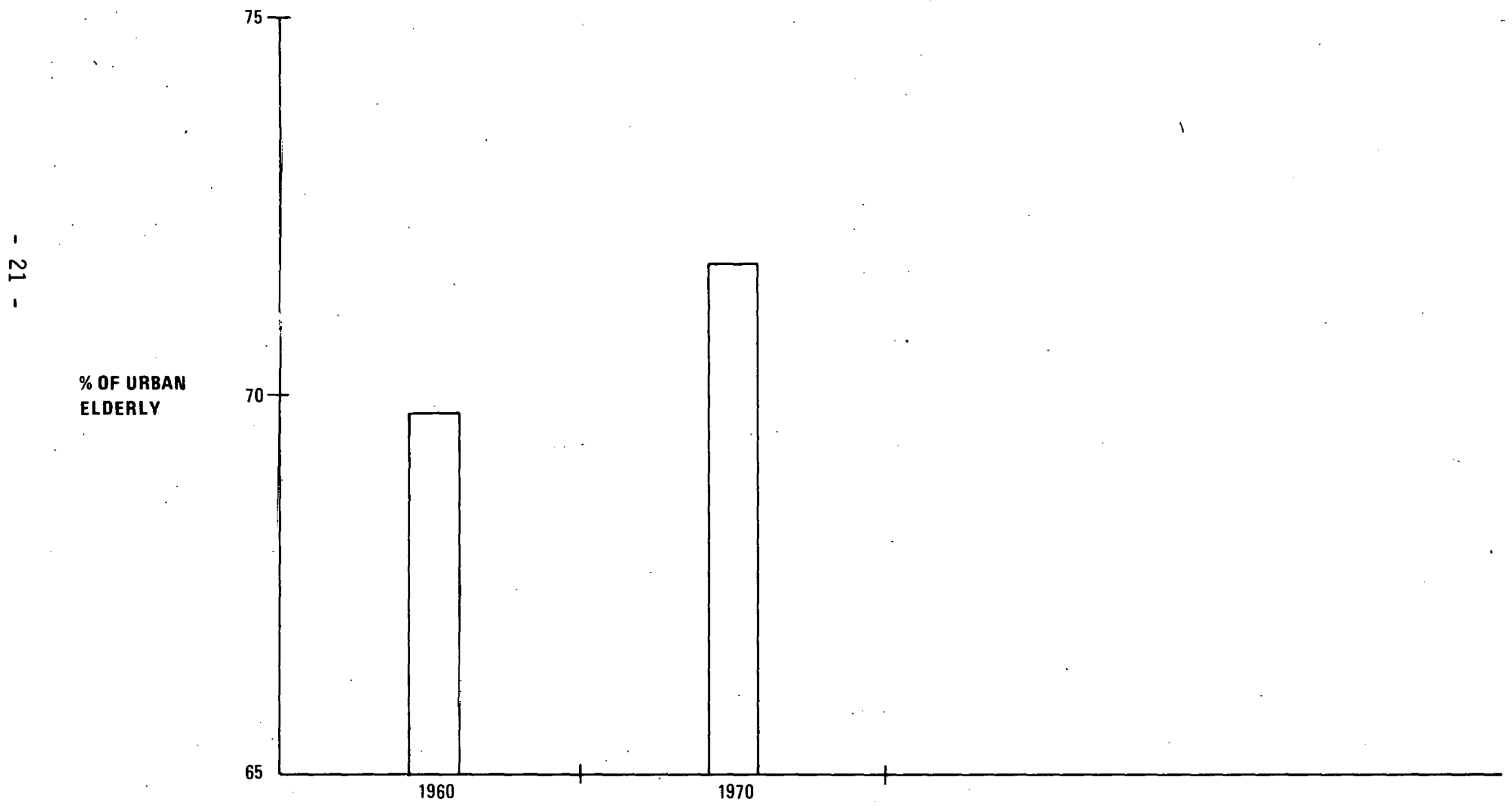


elderly with alternative energy systems utilizing direct use of solar energy.

The concentration of elderly in urban areas is obvious from the data represented in Table 4 and summarized in Figure 4, in which "urban" is defined as a place of 2,500 or more inhabitants. Nationally, nearly three-quarters of the elderly lived in such urban places in 1970, with even higher proportions shown in the Northeast and West regions. Comparable data for a post-decennial period are not available from published sources. However, the fact that so many elderly live in urban areas and probably in older housing units suggests that the elderly could benefit from a governmentally sponsored program to retrofit their homes. Because retrofitting of decentralized energy systems is difficult and expensive, more centralized energy systems seem to recommend themselves if installation and kWh costs can be kept low and within the means of the elderly. Data from the 1960 and 1970 .Censuses further indicate a very high concentration of elderly in the central cities. Of those elderly living in urbanized areas, over half (67.7 percent in 1960 and 61.6 percent in 1970) lived in the urban core. There is, however, some basis for speculating that the concentration of elderly in the central cities has declined. A recent study by the Bureau of the Census on metropolitan areas $^{6}$ indicates that, although there was an increase in the number of elderly in metropolitan areas between: 1970 and 1977, the rate of growth was seven times greater in the suburban areas than in the central city. If such a pattern persists, many more of the future elderly will reside in the suburbs that surround the urban center, despite the fact that suburban housing is more expensive. Transportation is a problem, especi. ally for the elderly and many other facets of daily life are more expensive. If this trend persists, the case for centralized or decentralized energy will be decided on the basis of when the homes were built. If they are existing homes, they will require retrofitting, which suggests electrical systems. If they are to be new homes, a wider variety of options is available.

6 U.S. Bureau of the Census, "Social and Economic Characteristics of the Metropolitan and Nonmetropolitan Population: 1977 and 1970," Current Population Reports, Series P-23, No. 75 (Washington, DC: U.S. Government Printing Office, 1978). 


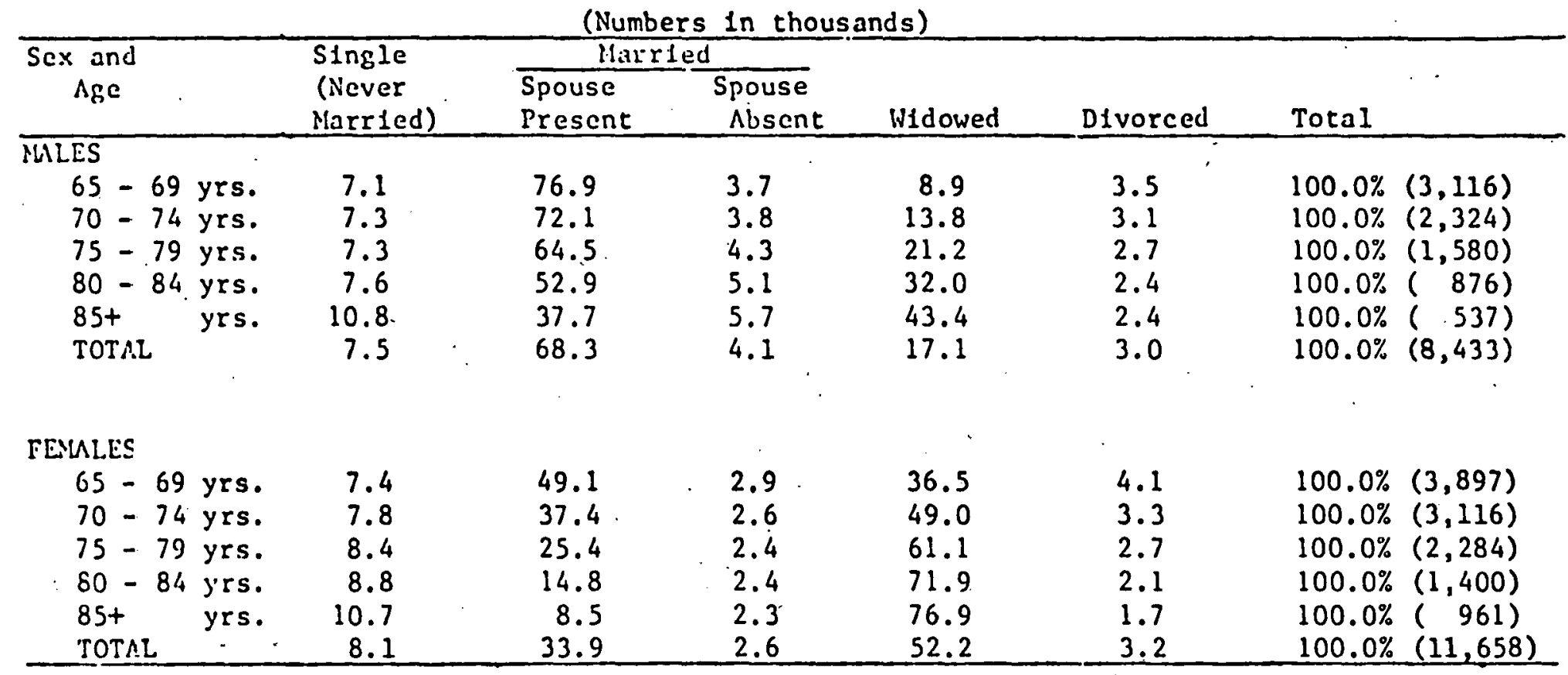

Source: United States Bureau of the Census. 1970 Census of the Population. "Detailed Characteristics, United States Summary, PC(1)-D1." Table 203. 
FIGURE 5: LIVING ARRANGEMENTS

PERSONS 65 AND OVER

1970

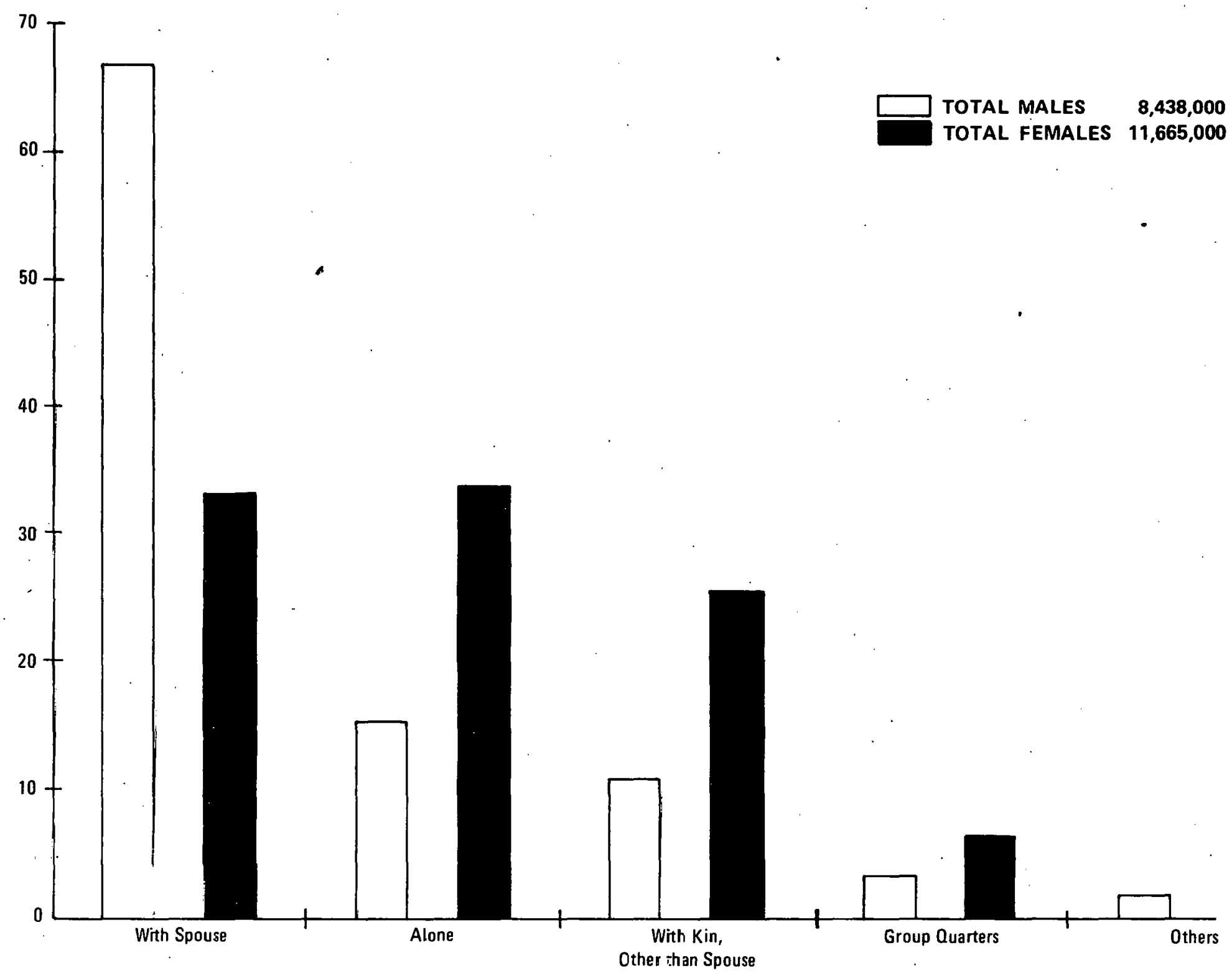


Table 6 .

Percentage Distribotion of Living Arrangements for

Persons Age 65 and Older, by Sex and Age: 1970

(Numbers in thousands)

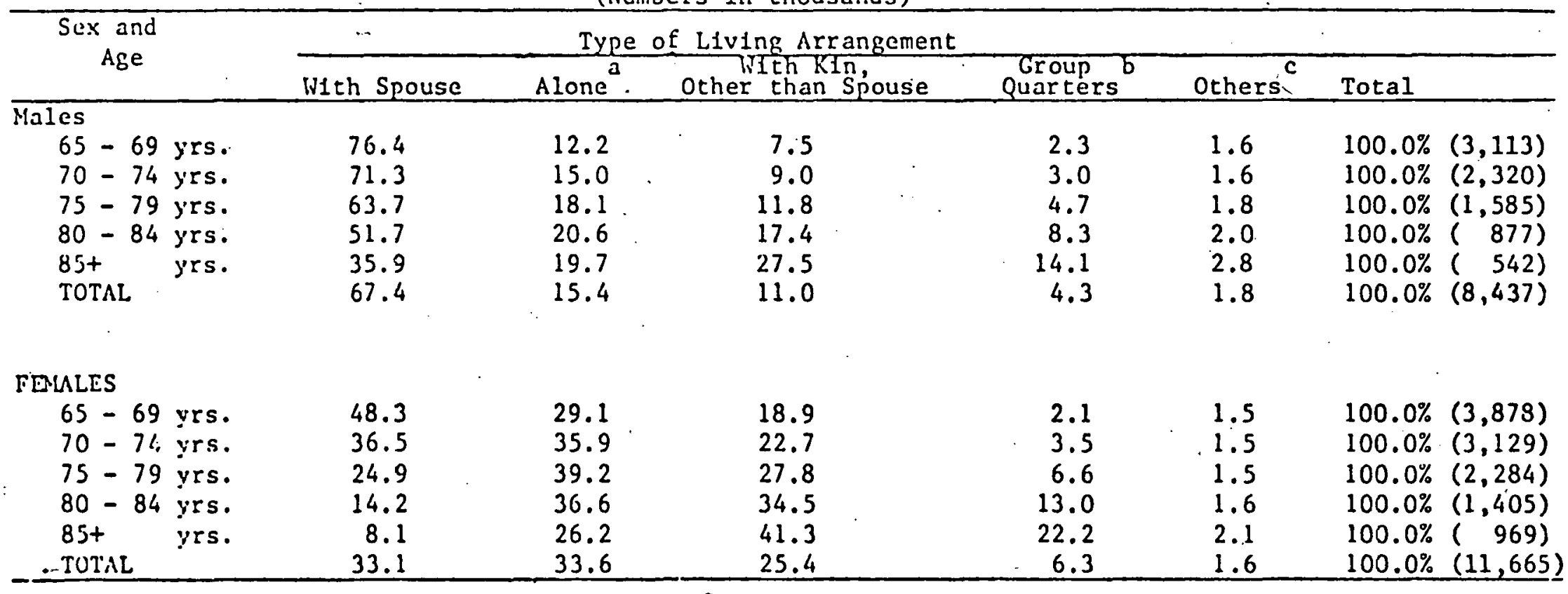

"Primary Individuals, 1.e., persons living alone or head of household containing only unrelated individuals.

b Inmates 10. Institutions and Persons Living in Group Quarters.

c Sccondary Individuals, 1.c., unrelated persons in a houschold.

Source: United States Bureau of the Census. 1970 Census of the Population. "Detalled Character1st1cs, United; States Summary, PC(1)-DI." Tables 204 and 205. 
Migration patterns of the elderly are commonly thought to involve retirement-related moves. A study by Long and Hansen ${ }^{7}$ indicates that, al though many older persons give retirement as a reason for interstate migration, many also cite a desire to change climate, to be closer to relatives or some other family reason. On the whole, however, the elderly exhibit a low tendency to move. In 1970, for example, approximately 70 percent of the elderly lived in the same houses as they did in 1965. Another 20 percent moved within the same state or county. Persons in the West showed a somewhat greater propensity to move than did those in other regions. ${ }^{8}$ if the elderly do migrate across state lines, the tendency has been to move to another state within the same region or to move to states in the South or West.

D. Social Characteristics

The process of aging engenders changes in many social characteristics. Changes in marital status are perhaps the most common. As Table 5 and Figure 5 indicate, the proportion of elderly persons living without spouse increases with advancing age. Differences in mortality patterns and the tendency of women to marry older men, have the effect of increasing the probability of widowhood for women. Over 50 percent of older women are widowed, compared with less than one in five older men. The data show that, except at the very oldest ages, the majority of men is Illarrted with spouse present. The majority of women, on the other hand, is widowed. Single, divorced and separated persons represent only a smali proportion of today's older population.

Table 6 shows the pattern of living arrangements among the elderly. Because the majority of men is married with spouse present, most older males maintain households with their spouses. For unmarried older persons of either sex, living alone is the most common arrangement. Onily with advancing age (and perhaps declining health) is there an

7 L.H. Long and.K.A. Hansen, "Reasons for Interstate Migration: Jobs, Retirement, Climate and Other Influences." Paper presented at the Southern Regional Demographic Group, San Antonio, Texas, 1978.

8 B.J. Soldo and C.J..DeVita, "Profiles of Black Aged." Paper presented at the Conference on Blacks and Retirement: An Untapped National Resource; sponsored by the Council on Minority Planning and Strategy, Washington, DC, 1978. 
increase in the proportion of elderly living with family members or in an institutional setting.

Results from several small surveys of older whites indicate that older persons prefer to live independently. 9,10 In good health, living independently, even alone, is the arrangement consistently preferred to living with relatives. Most older whites, particularly women, advocate maintaining their own homes: but also want to reside near an adult child or stay in close contact with their kin.

The ability to live alone is also correlated with an older person's financial well-being. Individuals with low incomes are constrained in their. housing options and, therefore, tend to share accommodations more often than those at higher income levels.11,12

Another social characteristic of importance is the "self-perception" of the elderly, largely influenced by social attitudes toward the elderly.

During the past century, U.S. society has developed a negative, stereotyped attitude often.called "ageism" toward the elderly, who have come to be regarded as sickly, unproductive, depressed and depressing individuals. Unfortunately, the formerly held cultural view, which associated old age with wisdom and prudence, has been swept away in contemporary society. The present-day U.S. image of the elderly is that of senility and impotence. This negative attitude toward the elderly has been scientifically explored, and it must be challenged.

Psychological trauma can be as damaging as physical ones, and the atmosphere of modern society places the elderly in social circumstances in which psychological trauma can be easily evoked. The most harmful

9 E. Shanas., P. Townsend, et al., old People in Three Industrial Societies, (New York: Atherton Press, 1968).

10 H.Z. Lopata, widowhood in an American City, (Cambridge, Massachusetts:' Sahenkman Press, 19/i).

11 B.K. Soldo, The Determinants of Temporal Variations in Living Arrangements Among the E1derly: 1960-1970. Unpublished Ph.D. dissertation, Duke University, 1977.

12 B.J. Soldo and P. Lauriat, "Living Arrangements Among the Elderly in the United States: A: Log-Linear Approach," Journal of Comparative Family studies, 7: 351-366, 1976. 
effect of society's attitude is that the elderly tend to adopt the view of themselves that society projects and to yield passively to judgments on their conservatism, preoccupation with health, inability to learn, loss of cognitive functions, etc. This is unfortunate because the stereotype is inaccurate. Tens of thousands of retirees each year burn old bridges, move to totally different regions, and embrace new and unfamiliar life-styles. Both they and those who stay in place often train for and embark on "second careers." In many cases, the elderly are the volunteer mainstays of essential service organizations. The community colleges are jammed with retired mechanics who are studying literature or phllosophy, with elderly housewives taking courses in real estale or yeuluyy ur ledrning tu square-dance. Nor are the aged resistant to innovation, as is demonstrated by the example of the residents of the Friends House Nursing Home in Silver Spring, Maryland, who have voted for the long-term investment of solar heating.

\section{E. Economic Status}

The financial well-being of an individual at any age is frequently a reliable indicator of his or her personal autonomy. Limited financial resources restrict the range of alternatives by which an elderly person can adjust to old age. Simply stated, money enables the older person to purchase needed, or desired, goods and services.

on the average, the elderly have much lower incomes than younger age groups, primarily because of a decrease in income that usually accompanies retirement. Brotman 13 estimates that, "retirement brings a reduction of between one-half and two-thirds in money income as retirement benefits replace earnings as the principal source of income." In 1974, the median income of families with heads age 65 or older was $\$ 7,298$ compared with $\$ 12,836$ for all families -- or three-fifths of the national norm. Families with a female head had lower median incomes than those headed by a male. The median income of unrelated individuals (i.e., those not living with a relative) over age 65 was only $\$ 2,956$ in 1974.14

13 H.B. Brotman, "The Economics of Aging." Paper presented at the . Conference on Aging; University of Miami, Coral Gables, Florida, 1974.

14 Seigel, loc. cit. 
Table 7. Percentage Distribution of Total Money Income for Persons Age 65 and Older, by Family Status: 1976

\begin{tabular}{lcc}
\multicolumn{3}{c}{ (Numbers in thousands) } \\
$\begin{array}{l}\text { Total Money } \\
\text { Income }\end{array}$ & Head of Fanily & Unrelated Individuals a \\
\hline Under $\$ 2000$ & $1.3 \%$ & $10.5 \%$ \\
$\$ 2,000-3,999$ & 9.9 & 47.5 \\
$\$ 4,000-5,999$ & 18.1 & 19.8 \\
$\$ 6,000-7,999$ & 15.9 & 9.2 \\
$\$ 8,000-9,999$ & 12.2 & 4.5 \\
$\$ 10,000-14,999$ & 19.6 & 5.1 \\
$\$ 15,000-19,999$ & 10.6 & 2.0 \\
$\$ 20,000-24,999$ & 5.1 & 0.5 \\
$\$ 25,000+$. & 7.4 & 0.9 \\
& & \\
TOTAL & $100.0 \%$ & $100.0 \%$ \\
\end{tabular}

${ }^{\text {a }}$ Over $95 \%$ of these persons are classified as Primary Individuals.

Source: United States Bureau of the Census. Current Population Reports. Series P-60, No. 114, Issued July 1978.

"Money Income in 1976 of Families and Persons in the United States." Tables 20 and 21 : 
FIGURE 6: ELDERLY INCOME

1976

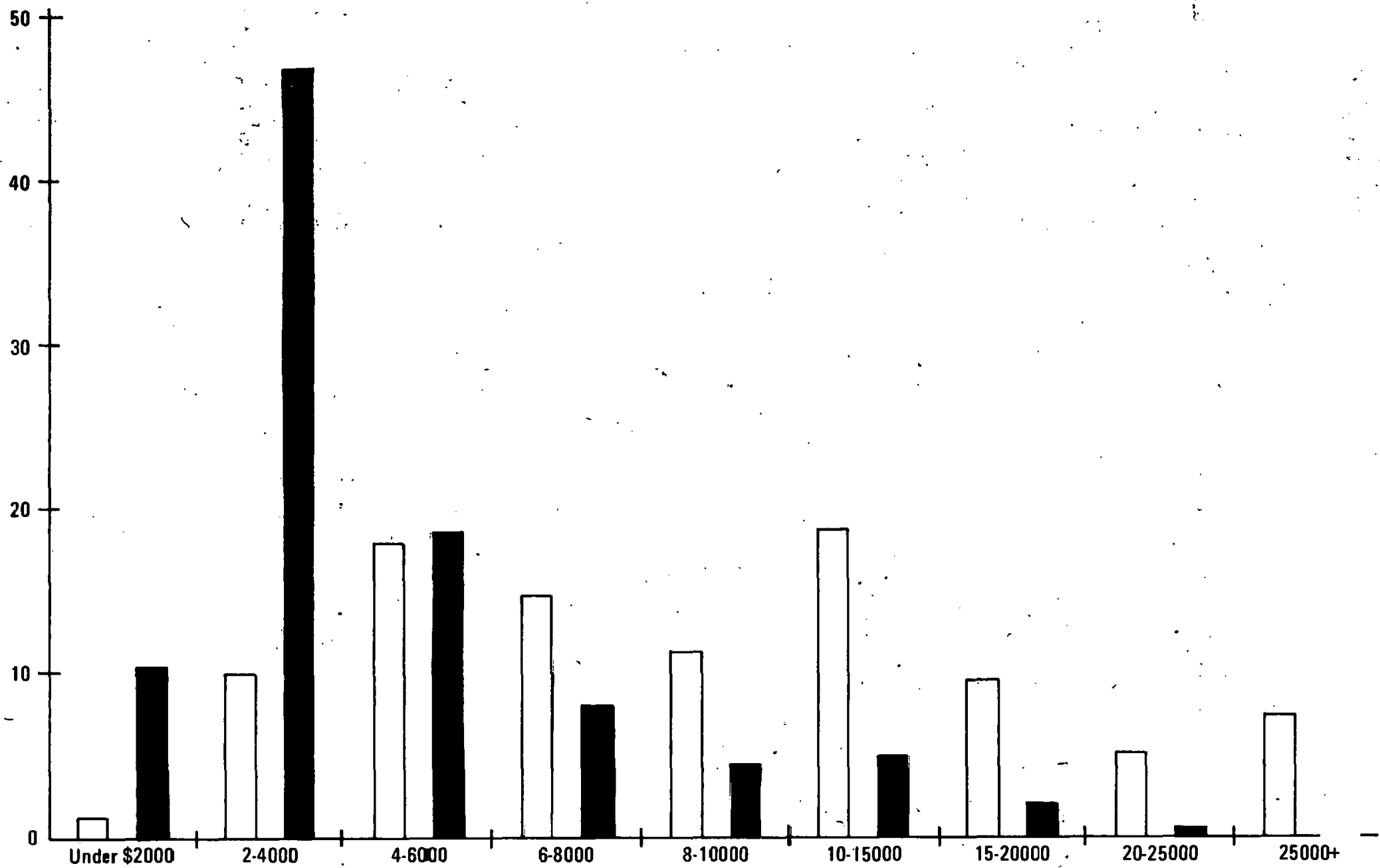


Table 8.

Poverty Rates for the Population Age 65 and 01der, by Region, Metropolitan - Nonmetropolitan Place of Residence and Family Status: 1975.

\begin{tabular}{|c|c|c|c|c|c|}
\hline \multirow[b]{2}{*}{$\begin{array}{c}\text { Metropolitan and Family } \\
\text { Status }\end{array}$} & \multicolumn{5}{|c|}{ Percent of Total Below Poverty Level } \\
\hline & United States & North \& Wes $\frac{R}{t}$ & South & & \\
\hline Total & & . & $\vdots$ & & \\
\hline $\begin{array}{l}\text { Persons } 65+ \\
\text { In fanilies, head } 65+ \\
\text { Not in families }\end{array}$ & $\begin{array}{r}15.3 \\
8.9 \\
31.0\end{array}$ & $\begin{array}{r}11.3 \\
5.3 \\
25.0\end{array}$ & $\begin{array}{l}23.7 \\
16.0 \\
44.6\end{array}$ & & \\
\hline Metropolitan & & & & & $\therefore$ \\
\hline $\begin{array}{l}\text { Persons } 65+ \\
\text { In families, head } 65+ \\
\text { Not in families. }\end{array}$ & $\begin{array}{r}12.0 \\
6.1 \\
26.3\end{array}$ & $\begin{array}{r}9.8 \\
4.6 \\
22.1\end{array}$ & $\begin{array}{l}18.6 \\
10.2 \\
39.4\end{array}$ & $\because$ & . \\
\hline Nonmetropolitan & & . & & & \\
\hline $\begin{array}{l}\text { Persons } 65+ \\
\text { In families, head } 65+ \\
\text { Not in families }\end{array}$ & $\begin{array}{l}21.0 \\
13.4 \\
39.5\end{array}$ & $\begin{array}{r}14.8 \\
6.7 \\
31.9\end{array}$ & $\begin{array}{l}28.5 \\
21.0 \\
50.1\end{array}$ & & 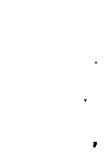 \\
\hline
\end{tabular}

Source: United States Bureau of the Census.. Current Population Reports. Series P-60, No. 106, Issued June 1977.. "Characteristics of the Population Below the Powcrty Level: 1975." "Table: 9: 


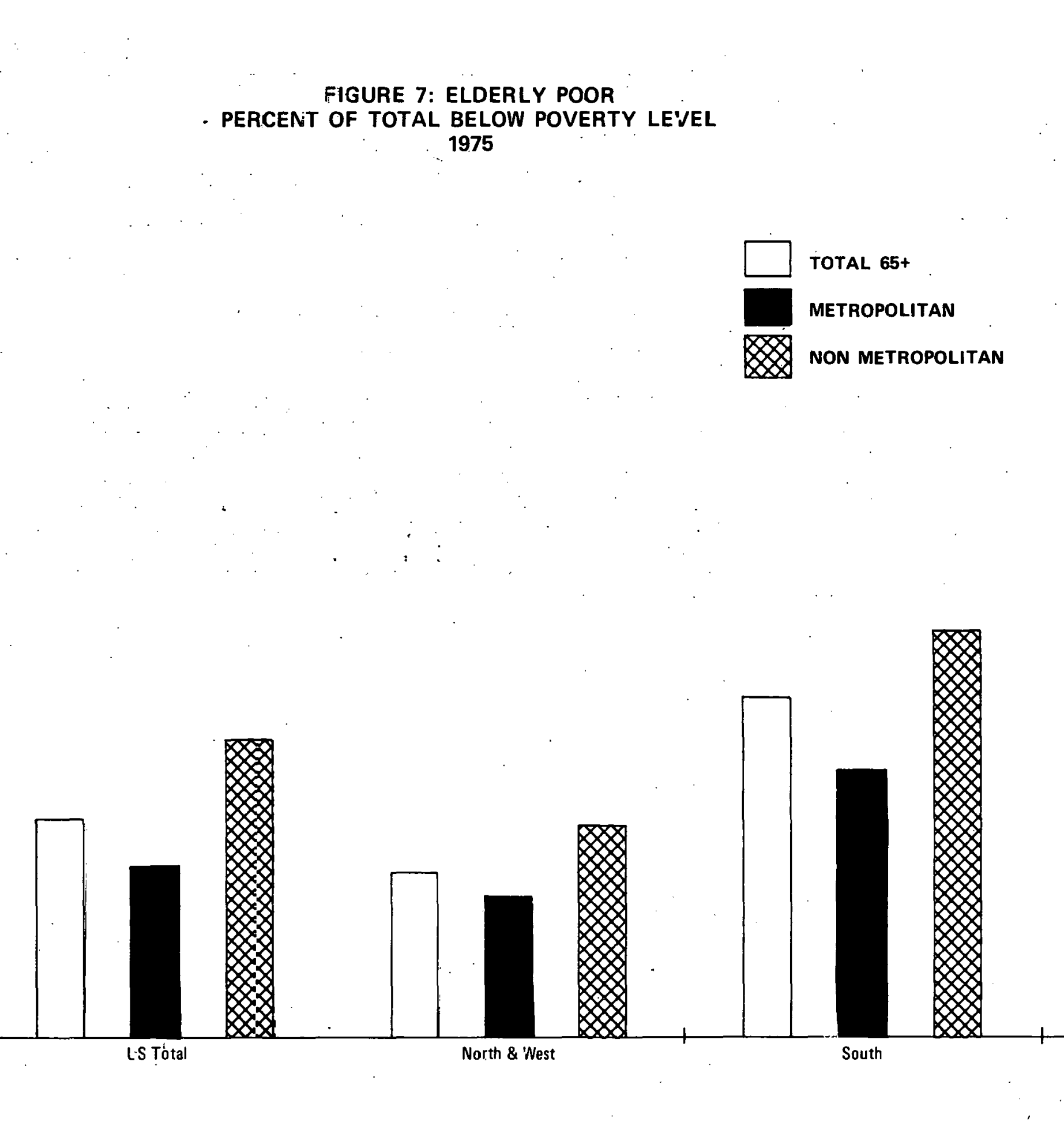


These statistics suggest that the energy needs of the elderly will have to be subsidized by the government in one form or another. Whether this is through direct subsidization such as so-called "energy stamps," through subsidizing retrofitting installations, or through a federaliy sponsored SSPS with reduced rates, is a moot question.

Table 7 and Figure 6 show the distribution of total money, income for heads of families and unrelated individuals in 1976. These data indicate a broader range of income level for family heads than for persons living outside a family unit. The median income for families with the head age 65 or older falls between $\$ 8,000$ and $\$ 10,000$. For unrelated individuals, the median is less than $\$ 4,000$.

Comparing total-money-income distribution, or statistics based on such a distribution, can be misleading unless controls are introduced for the size of the family and the size of the place of residence. Because the cost-of-living varies between urban centers and rural areas, total money income does not indicate the adequacy of a specific level of income. A useful summary of income adequacy is provided by the povertylevel concept. Originally developed by the Social Security Administration in the mid-1960's, the poverty-level cutoff is adjusted for such factors as family size, sex of family head, number of children under 18 years of age, and farm/non-farm residence. The poverty-level income cutoffs are revised each year with reference to the annual consumer Price Index.

In 1975, the poor aged represented 12.8 percent of all persons living in poverty. This proportion is increased to 15.3 percent when the population age 65 and over is used as the denominator. Variation in the 1975 poverty rates of the elderly by region, place of residence, and family status are shown in Table 8 and Figure 7 . The data indicate that the rates of poverty among the older population are twice as great in the South as in the North and West regions, and that metropolitan areas show lower proportions of elderly in poverty than do non-metropolitan areas, regardless of region. The major predictor of income adequacy appears to be family status. Depending on region and place of residence, one-quarter to one-half of persons age 65 and over who are not living in a family have incomes below the poverty level. In contrast, only 9 . percent of all families with the head 65 or older are in poverty. The 
Table 9 Percentage of Persons Age 65 and Older Receiving Income

From Selected Sources by Family Status: 1976

(Numbers in thousands)

\begin{tabular}{|c|c|c|}
\hline Source of Income & $\begin{array}{l}\text { Head of } \\
\text { Family }\end{array}$ & $\begin{array}{r}\text { Unrelated } \\
\text { Individuals }\end{array}$ \\
\hline $\begin{array}{l}\text { Earnings Only } \\
\text { Wage or salary only } \\
\text { 3elf-empluyment income only } \\
\text { Wage or salary and self-employment income }\end{array}$ & $\begin{array}{c}1.3 \% \\
76.9 \\
6.7 \\
16.3\end{array}$ & $\begin{array}{r}1.4 \% \\
94.9 \\
2.0 \\
3.0\end{array}$ \\
\hline Earnings and Income Other Than Earnings & 47.3 & 16.1 \\
\hline $\begin{array}{l}\text { Other Income Only } \\
\text { Social Security only } \\
\text { Public assistance income only } \\
\text { Pension income only } \\
\text { Pension and property income only } \\
\text { Social Security and other income } \\
\text { Other combination of other income, excluding. } \\
\text { Social Security }\end{array}$ & $\begin{array}{r}51.4 \\
14.8 \\
0.3 \\
(x) \\
1.0 \\
62.2 \\
21.6\end{array}$ & $\begin{array}{r}81.9 \\
20.7 \\
0.3 \\
0.4 \\
1.7 \\
50.9 \\
25.9\end{array}$ \\
\hline Total & $\begin{array}{l}100.0 \% \\
(8,141)\end{array}$ & $\begin{array}{l}100.0 \% \\
(7,027)\end{array}$ \\
\hline
\end{tabular}

(X) Base less than 10,000

${ }^{\text {a }}$ Over $95 \%$ of these persons are classified as Primary Individuals.

${ }^{b}$ Includes a small number of persons reporting no money income.

Source: United States Bureau of the Census. Current Population Reports. Series P-60, No. 114, Issued July 1978. "Money Income in 1976 of Families and Persons in the United States". Tables 31 and 32. 
FIGURE 8: ELDERLY INCOME SOURCES

1976

w

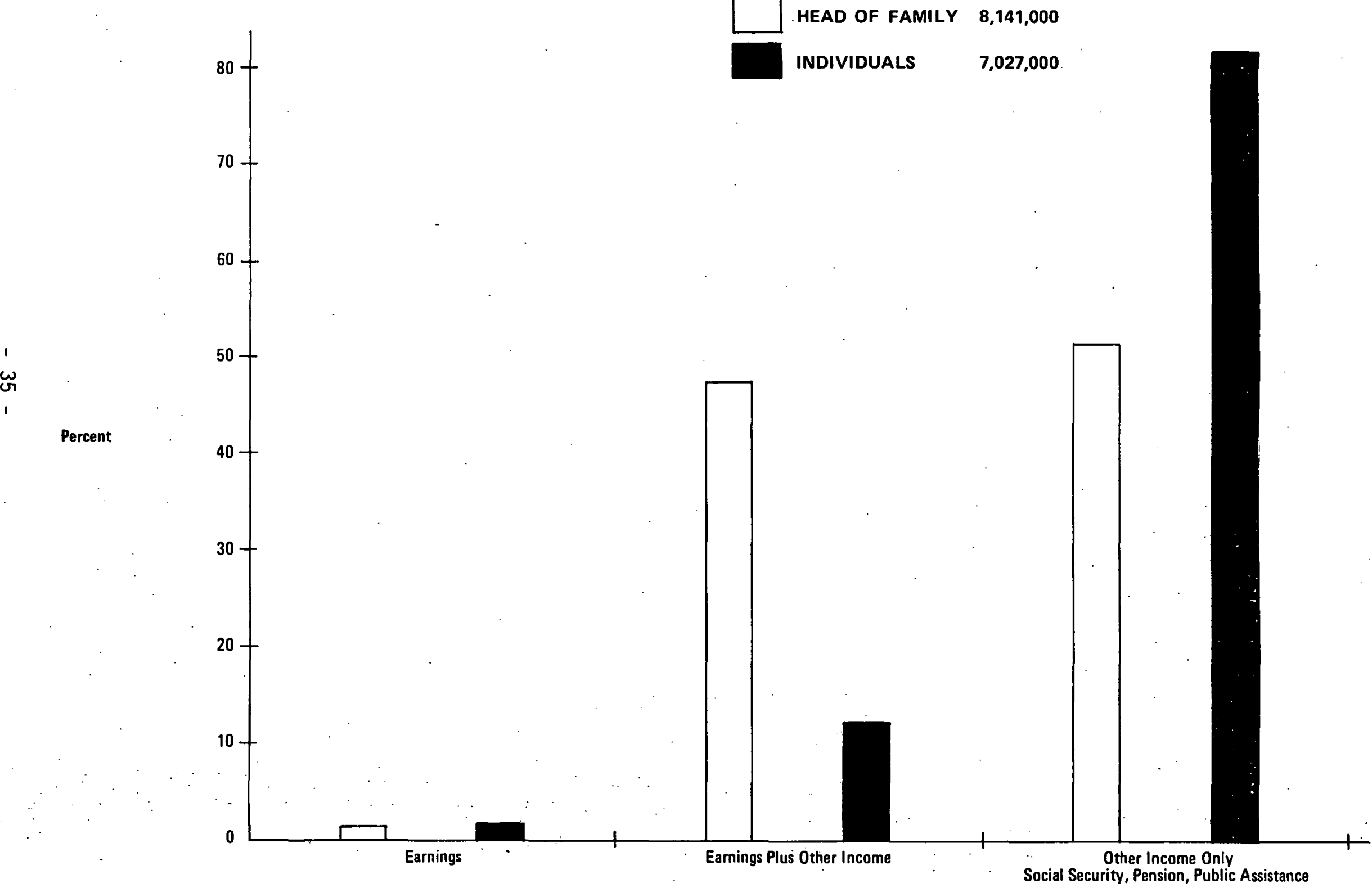


highest poverty rates occur among the elderly in the non-metropolitan areas of the South who do not live in a family environment; 50 percent of these persons have incomes below minimal standards, and they need some energy subsidy such as energy stamps, preferred rates, or outright purchase of equipment for them.

Money income is defined in the official statistics to include amount of income received: from earnings, Social Security, railroad retirement and other pensions, public-assistance and welfare programs, interest and dividends. In-kind income, such as fond stamps, subsidized housing, health benefits, and farm products for home consumption are specifically. excluded. As the data in Table 9 as summarized in Figure 8 indicate, the majority of older persons rely on income sources other than earnings. Over three-quarters receive some income from the Social Security system, with as many as one-fifth dependent exclusively on these payments. A family with the head age 65 or older is three times more likely to receive income from a combination of earnings and other income than is the older person who lives alone. Eighty-two percent of the elderly who live outside families and outside institutional settings receive income from sources other than earnings. Although mosl receive support from Social Security benefits, one-quarter report income solely from suurces other than social Socurity, such as pensions, public assistance, and property income.

The issue of income adequacy has received much attention in the past two decades, and some success has been achieved in reducing the proportion of older persons who maintain households below the poverty leve1. But the fears and the problems of living on limited or fixed financial resources, especially during inflationary times, must be considered in devising programs targeted at the older population.

\section{F. Housing Characteristics}

1. Characteristics of Housing

Although data are readily available for analyzing many of the social and economic characteristics of the older population, less is known about the housing situation of elderly Americans. Most of our knowledge in recent years has come from two primary sources: the decennial Census of Housing and the Annual Housing Survey, begun in 1973 
(Numbers in thousands)

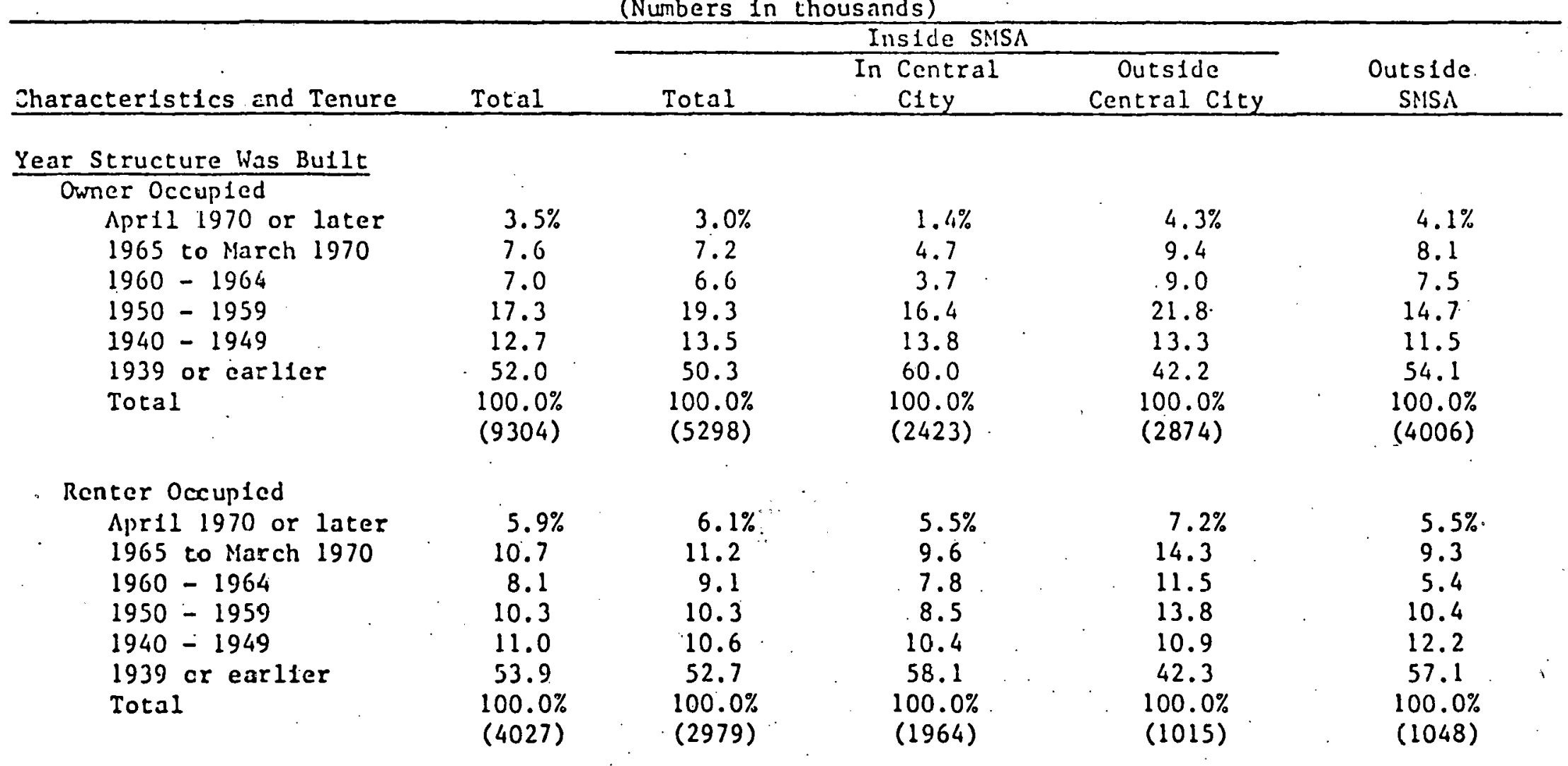

Number of Rooms

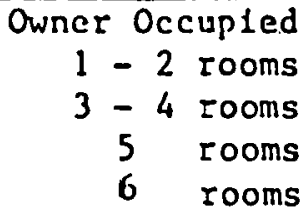

Owner Occupled

1 - 2 rooms

3 - 4 rooms

5 rooms

6 rooms

Total

Median Number of Roons

$\begin{array}{cc}1.4 \% & 1.5 \% \\ 27.1 & 26.0 \\ 29.9 & 30.1 \\ 23.5 & 25.0 \\ 18.1 & 17.3 \\ 100.0 \% & 100.0 \% \\ (9304) & (5298)\end{array}$

5.2

$1.3 \%$
23.6
31.7
26.8
16.7
$100.0 \%$
$(2423)$

5.2
5.3

$1.8 \%$
28.1
28.8
23.5
17.9
$100.0 \%$
$(2874)$

$1.3 \%$

28.4

29.6

21.5

19.2

$100.0 \%$

(4006) 
Table 10.

continued

(Numbers in thousands)

\begin{tabular}{|c|c|c|c|c|c|c|}
\hline & & \multicolumn{3}{|c|}{ Inside SNGSA } & \multicolumn{2}{|l|}{$\because \vdots$} \\
\hline Characteristics and Tenure & Total & Total & $\begin{array}{c}\text { In Central } \\
\text { Clty }\end{array}$ & $\begin{array}{c}\text { Outside } \\
\text { Central C1ty }\end{array}$ & $\begin{array}{c}\text { Outside } \\
\text { SMSA }\end{array}$ & ' \\
\hline
\end{tabular}

Nimiser of Rooms

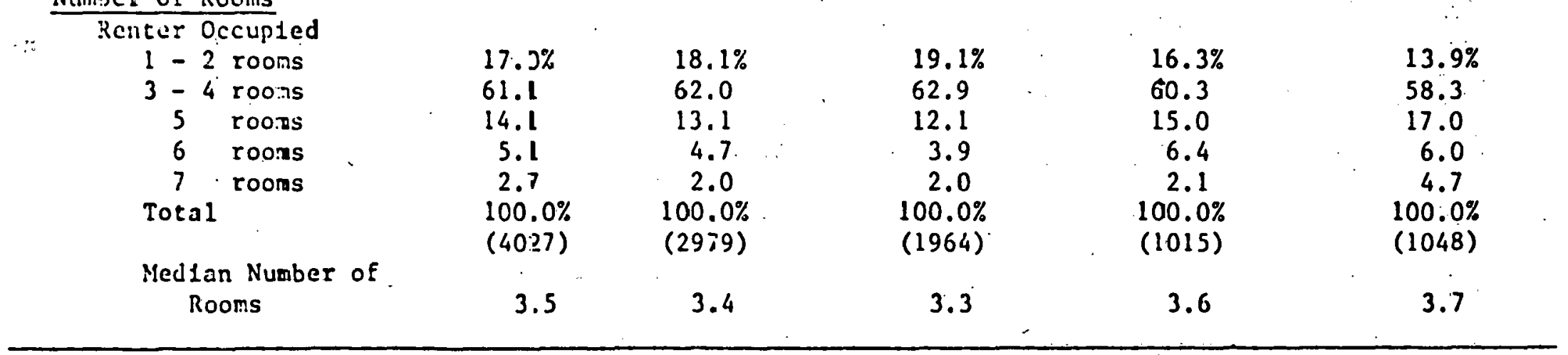

Source: Data obtalned fror. unputlished tabulaticns on elderly househalds from the 1973 Annual llousing Survey, prepared by the Phi-adelphia Ceriatric Center for the Defartment of Housing and Urban Developtient. 
FIGURE 9: AGE OF ELDERLY HOUSING

1973

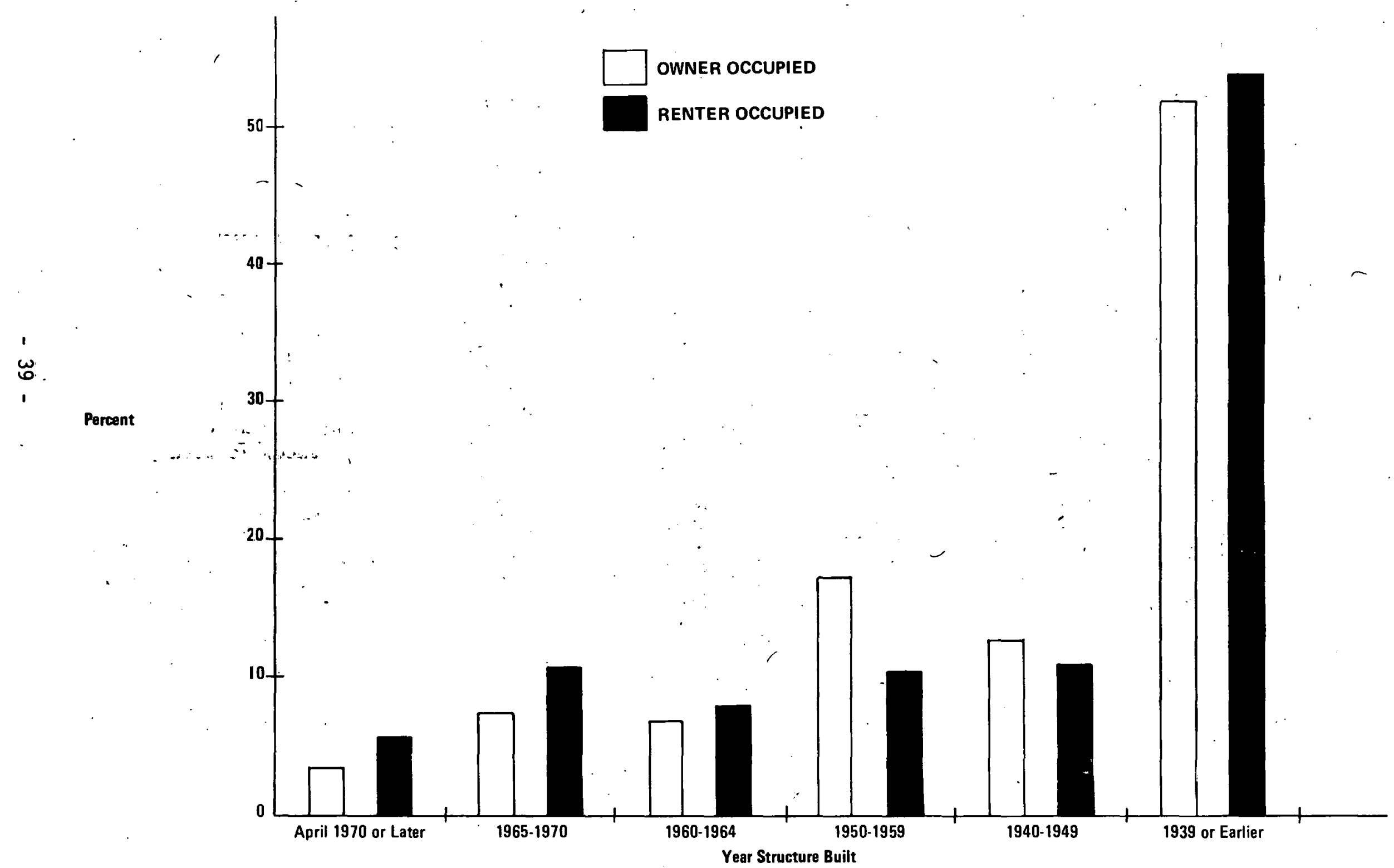


under the auspices of the Department of Housing and Urban Development and the U.S. Bureau of the Census. From these sources, data are avai1able to ascertain a national picture of the physical characteristics of the housing stock, as well as some measure of housing quality.

Several limitations must be kept in mind when one is discussing housing characteristics of the elderly. First, a household is conventionally defined in terms of the age of the head. Many older persons, particularly those living with kin, reside in households in which the head is younger than age 65 . The discussion that follows, therefore, must be restricted to units that arc headed by an elderly individual. Second, the available data do not distinguish between types of living arrangements. It is, therefure, Impossible to determine if the household is maintained by a single individual, a husband-and-wife team, a multigenerational family, or several unrelated individuals. Third, data are not available by state or region but only on a national scale.

The best in-depth analysis of the housing situation of the elderly to date has come from the 1973 Annual Housing Survey. ${ }^{15}$ The data show a higher rate of home ownership among the elderly (70 percent) compared with the general population ( 65 percent). Almost three-quarters of the older population have at.tained the American ideal of owning their own homes. But in what types of housing units do the elderly live?

Table 10 and Figure 9 give information on certain physical characteristics of the housing stock. For both renters and owners, a majority of elderly households occupy buildings that were constructed prior to 1940. This tendency is especially stong in the central cities but also holds for persons living outside the Standard Metropolitan Statistical Areas (SMSAs). Only 11 percent of owners and 16 percent of renters 1 ive in dwellings after 1965. Unfortunately, data on the type of construction material used in these homes are unavailable. Chances are that they are

15 Most published data on housing characteristics do not control for the age of the head, making it impossible to separate older households from the general population. Tabulations specific to the elderly were prepared from the 1973 Annual: Housing Survey by the Philadelphia Geriatrics Center for the Department of Housing and Urban Development. The authors which to thank HUD for making these data available for this analysis. 
in Households with Head Age 65 or 0lder,

by Tenure and Metropolitan Status: 1973

(Numbers in thousands)

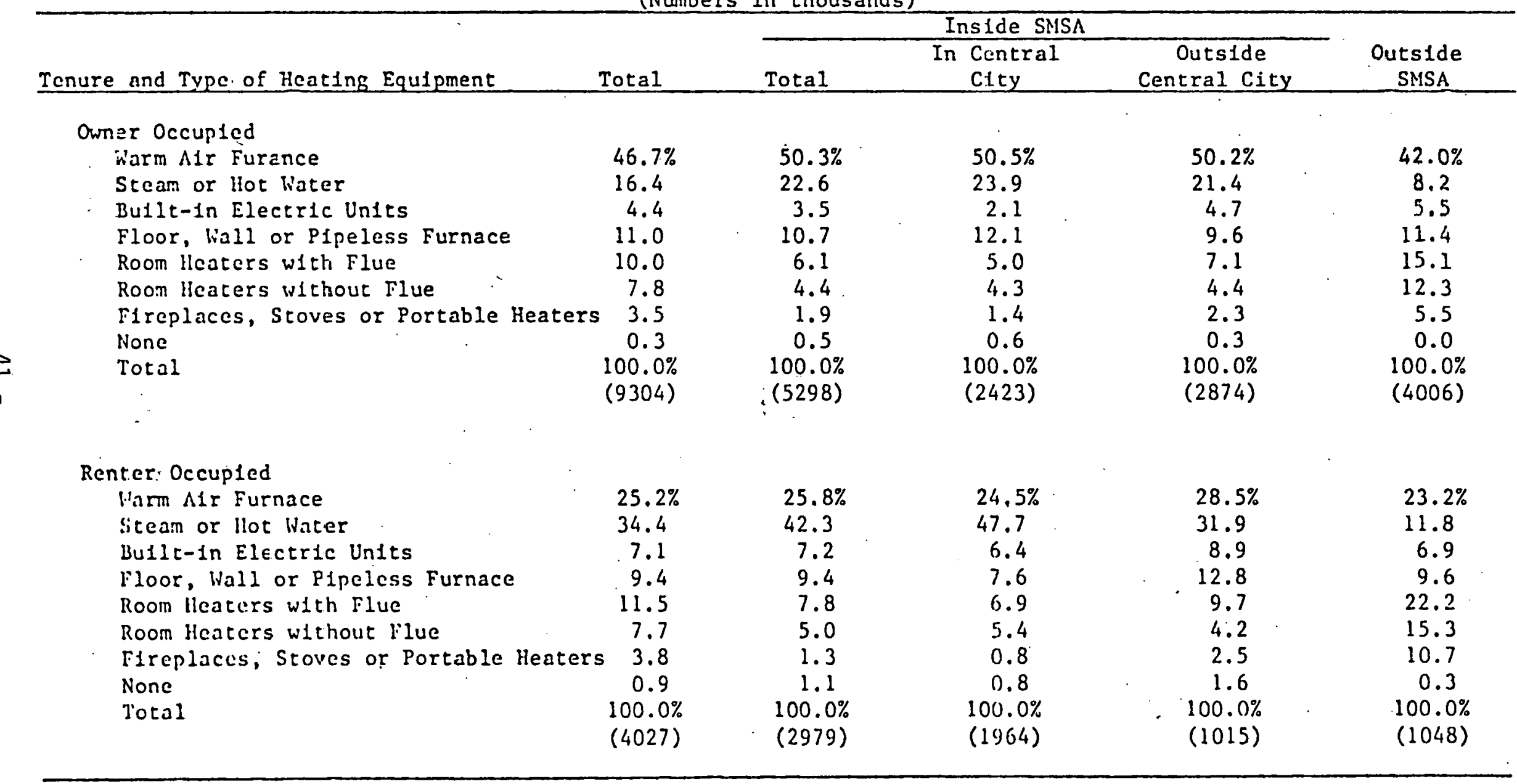

Source: Data obtalned from unpublished tabulations on elderly households from the 1973 Annual Housing Survey, prepared by the Philadelphia Geriatric Center for the Department of Housing and Urban Development. 
FIGURE 10: E!DERLY HEATING EQUIPMENT

1973

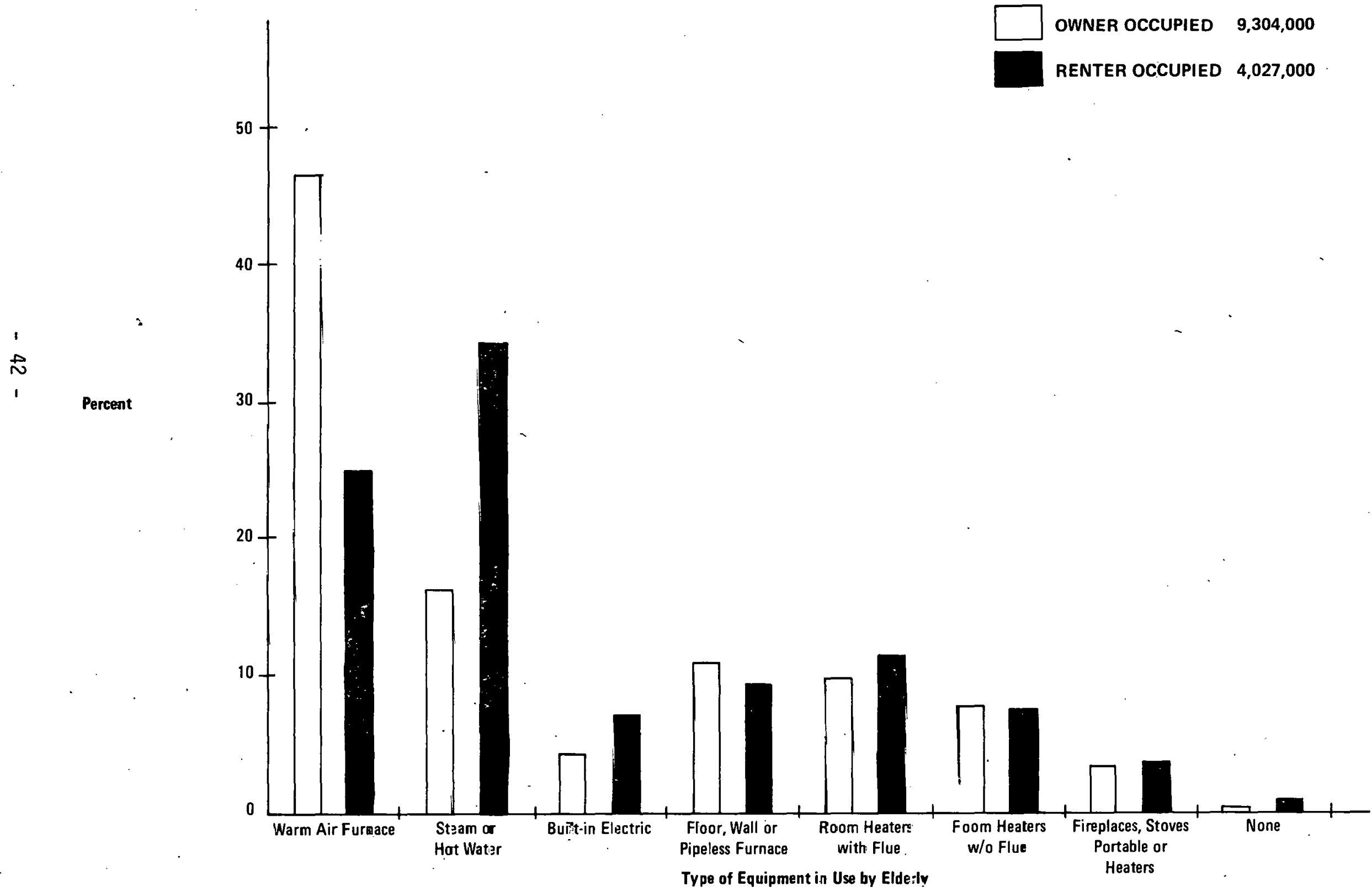


not very energy-conserving types, and that an amelioration of fossilfuel costs can come only from outright energy subsidies or from retrofitting.

It is possible, however, to determine the number of rooms in the household. As seen by the median number of rooms given in Table 10, elderly home owners occupy more space (5.2 rooms) than do elderly renters (3.5 rooms). The percentage distribution of the number of rooms does not vary substantialiy by place of residence but is quite diverse by tenure status. Ninety-eight percent of elderly home owners have a minimum of. three rooms in their homes. In contrast, over 75 percent of elderly renters have a maximum of four rooms. The additional space enjoyed by home owners is also likely to bring with it higher monthly maintenance and utility costs (particularly higher heating costs in the North and higher air-conditioning costs in the South).

Data on types of heating equipment can also be found in the Annual, Housing Survey (see Table 11, Figure 10). The most common types of heating equipment are warm-air furnaces (oil-or gas-fired) and steam (or hot-water) heat. The former predominate in owner-occupied residences, while the latter are more frequently found in rental units. Differences in utilization rates of various types of heating equipment can also be seen by prace of residence. Outside the SMSA's, elderly home owners are two and one-half times more likely to heat by room heaters (with or without flues) or by fireplaces and stoves than are owners within the SMSA's. For non-metropolitan renters, room heaters are three times more cumion than for their urban counterparts. Heating by means of a fireplace or stove is utilized by 11 percent of rural renters and only 1 percent of urban renters.

Relating these findings to the general population, it is found that proportionately fewer elderly households (67 percent of the elderly and 73 percent of the total population) have central-heating systems. This discrepancy is balanced by a higher utilization of room heaters by the elderly (28 percent to 23 percent, respectively). Lack of central heating and cooling can present some special problems for elderly households. As a person ages, an individual becomes less able physiologically to regulate body heat, and thus less sensitive to extremes in temperature. 
(Numbers in thousands)

\begin{tabular}{|c|c|c|c|c|c|}
\hline \multirow[b]{2}{*}{ Tenure and Type of Fuel } & \multirow[b]{2}{*}{ Total } & \multicolumn{3}{|c|}{$\begin{array}{l}\text { Inside SMSA } \\
\end{array}$} & \multirow[b]{2}{*}{$\begin{array}{c}\text { Outside } \\
\text { SMSA }\end{array}$} \\
\hline & & Total & $\begin{array}{c}\text { In Central } \\
\text { C1ty }\end{array}$ & $\begin{array}{l}\text { Outside } \\
\text { Central C1ty }\end{array}$ & \\
\hline $\begin{array}{l}\text { Omer Occupled } \\
\text { Ut1lity Gas } \\
\text { Bottled, Tank or LP Gas } \\
\text { Fue: O11, Kerosene, etc. } \\
\text { Electr1e1ty } \\
\text { Coal or Coke } \\
\text { Wooc } \\
\text { Other Fuel } \\
\text { None } \\
\text { Total }\end{array}$ & $\begin{array}{c}54.1 \% \\
9.2 \\
26.0 \\
7.3 \\
1.7 \\
1.4 \\
0.1 \\
0.3 \\
100.0 \% \\
(9304)\end{array}$ & $\begin{array}{c}61.3 \% \\
3.2 \\
26.6 \\
6.6 \\
1.3 \\
0.4 \\
0.1 \\
0.5 \\
100.0 \% \\
(5297)\end{array}$ & $\begin{array}{c}71.6 \% \\
0.5 \\
21.1 \\
4.6 \\
1.3 \\
(x) \\
0.2 \\
0.6 \\
100.0 \% \\
(2423)\end{array}$ & $\begin{array}{c}52.6 \% \\
5.6 \\
3: .2 \\
8.3 \\
1.3 \\
0.7 \\
i x) \\
(1.3 \\
100.0 \\
(2 \& 74)\end{array}$ & $\begin{array}{l}44.6 \% \\
17.0 \\
25.1 \\
8.3 \\
2.2 \\
2.7 \\
(x) \\
-- \\
100.0 \% \\
(4006)\end{array}$ \\
\hline $\begin{array}{l}\text { Renter Occupled } \\
\text { Utility Gas } \\
\text { Bottled Tank. Or LP Gas } \\
\text { Fuel O1l, Kerosene, etc. } \\
\text { Electricity } \\
\text { Coal or Coke } \\
\text { Wood } \\
\text { Other Fuel } \\
\text { None } \\
\text { Total }\end{array}$ & $\begin{array}{c}52.3 \% \\
4.4 \\
27.9 \\
10.7 \\
1.8 \\
1.4 \\
0.6 \\
0.9 \\
100.0 \% \\
(4027)\end{array}$ & $\begin{array}{c}53.0 \% \\
1.0 \\
31.7 \\
10.9 \\
1.3 \\
(x) \\
0.7 \\
1.1 \\
100.0 \% \\
(2979)\end{array}$ & $\begin{array}{c}52.5 \% \\
(X) \\
34.5 \\
9.7 \\
1.2 \\
-. \\
1.0 \\
0.8 \\
100.0 \% \\
(1964)\end{array}$ & $\begin{array}{c}53.9 \% \\
2.7 \\
26.3 \\
13.3 \\
1.7 \\
(x) \\
(x) \\
1.6 \\
100.0 \% \\
(1015)\end{array}$ & $\begin{array}{c}50.5 \% \\
13.8 \\
17.1 \\
9.9 \\
3.1 \\
4.9 \\
(x) \\
(x) \\
100.0 \% \\
(1048)\end{array}$ \\
\hline
\end{tabular}

(x) Base lass than 5.000

\section{-- Indicates zero}

Columns may not sum to $100.0 \%$ because of rounding and omission of categorles vith base under 5000 .

Source: Data obtalned-from unpublished tatulations on elderly households from the 1973 Annual Housing Survey, prepared by the Philadelphia Geriatric Center for the Department of Housing and Urban Development. 
Tenure and Metropolftan Status: 1973

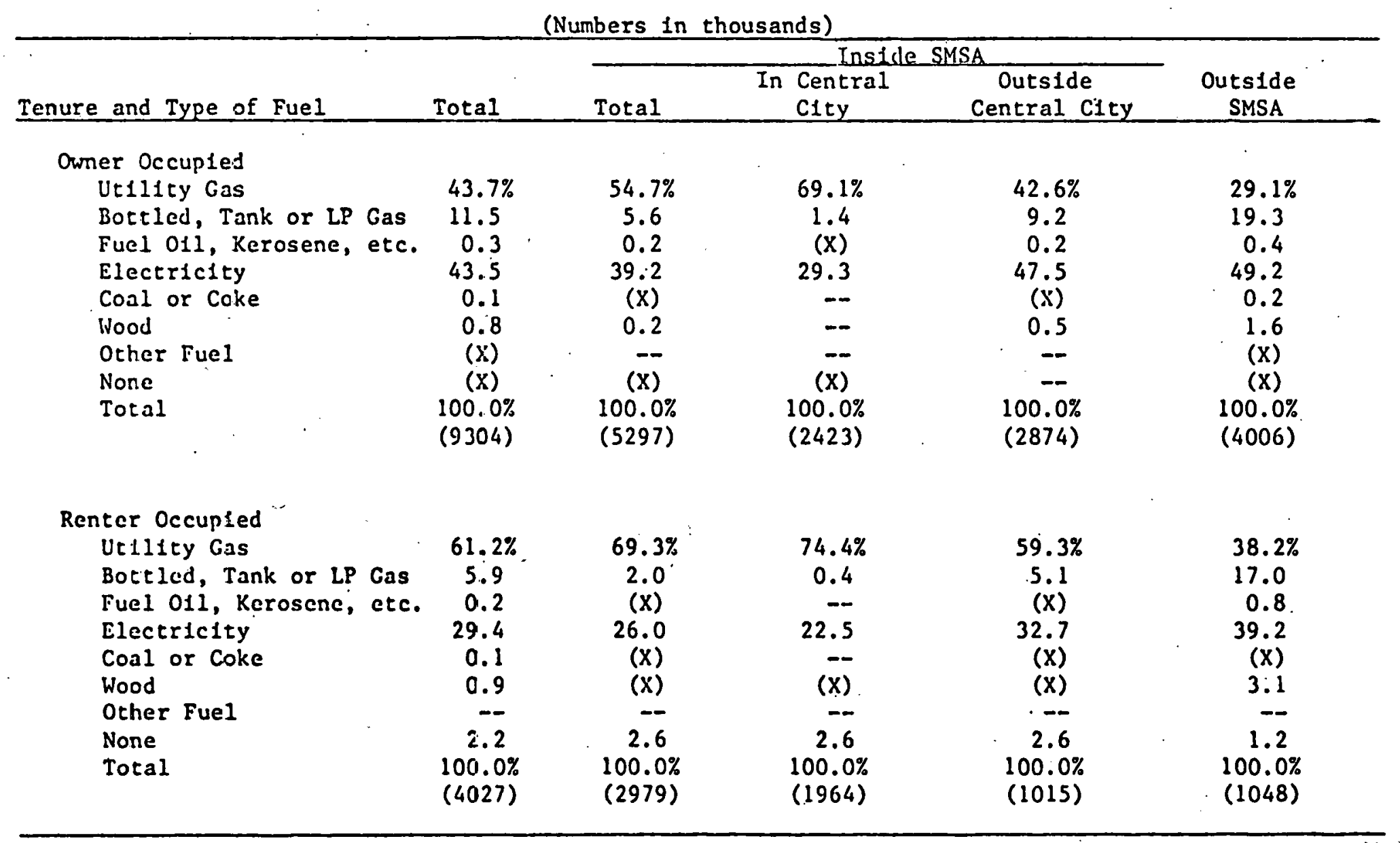

(x) Base less than 5,000

\section{-- Indicates zero}

Columns may no: sum to $100.0 \%$ because of rounding and bases of less than 5,000 .

Source: Data obtalned from unpublished tabulations on elderly households from the 1973 Annual Housing Survey, prepared by the Phlladelphia Gerlatric Center for the Department of Housing and Urban Development. 
FIGURE 11: ELDERLY FUEL USE BY TYPE

1973

i

Percent

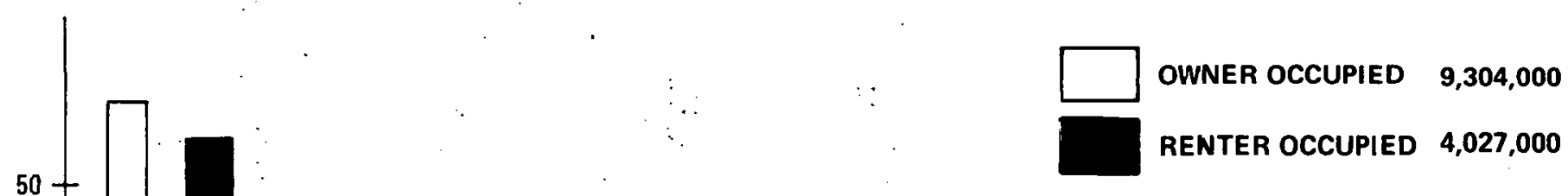

0 
FIGURE 12: ELDERLY COOKING FUEL BY TYPE

1973

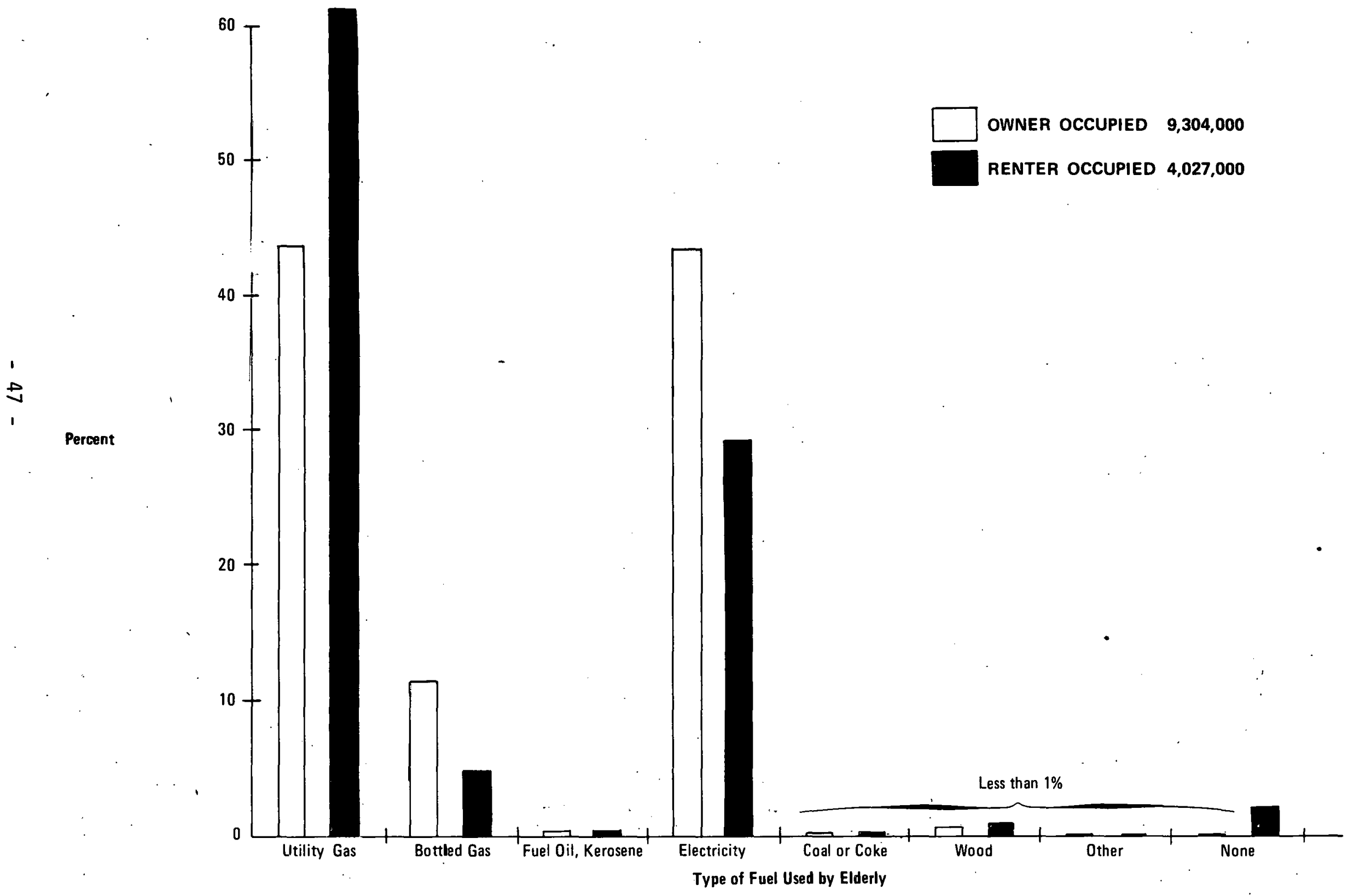


This condition, known as hypothermia, in extreme cases has resulted in the death of older persons who are unaware of excessively cold temperature and whose bodies do not automatically adjust to temperature changes. Similarly, aged persons are vulnerable to hyperpyrexia and cannot take unduty high temperatures.

Data on the types of fuel used for heating and cooking are presented in Tables 12 and 13, respectively. These are summarized in Figures 11 and 12. For the majority of households, regardless of tenure, utility gas is the primary fuel used for heating. Nearly three-quarters of home owners in the central city use this type of fuel, although one in five homes outside the SMSA's uses bottled or tank gas. Fuel oil is used for heating by one-quarter of elderly home owners, and a slightly higher propurtion of renteis lives in buildings with this type of heat. Electric heat is utilized by less than 10 percent of all households, with the remainder of homes being heated by other methods. Centralized energy systems could certainly be used in the homes utilizing electrical energy, which would amount to $7.3 \%$ of the total heating of households.

Almost 90 percent of elderly households use either utility gas or electric heat for cooking. Among home owners, this choice is almost evelly divided between the two fuels, although a higher proportion of central-city owners uses gas heat for cooking. Differences, again, appear in homes outside the SMSA's, with approximately 20 percent of owners using bottled or tank gas and 30 percent using utility gas in kitchen stoves. Among reriters, the majority of housing units is equipped with utility gas for cooking, but bottled or tank gas is not uncommon in the rurat areas.

In assessing heating problems of the elderly, a study by Struyk 16 found that, except in rural areas, heating systems were similar to those of the general population. The types of heating fuel used in older households was almost identical with that found in the population as a whole. Slightly more elderly households (10 percent) used additional heaters during a recent winter than did the total population ( 9 percent),

16 R.J. Struyk, "The Housing Situation of Elderly Americans," The Gerontologist, 17/2: 130-139, 1977. 
but somewhat fewer older persons ( 6 percent) reported heat breakdowns than did the general public ( 8 percent).

A greater discrepancy appears in the proportion of households containing rooms with no heating ducts or radiators. Nationally, 22 percent of households reported such conditions, but 31 percent of elderly households faced this situation. The problem is greater in rural farm households where 56 percent of the dwellings had some rooms without ducts or radiators. Not surprisingly, 20 percent of elderly farm households said they had closed some rooms in order to keep others warm, whereas only 7 percent of all elderly and 6 percent of all households took this action.

\section{Housing-Related Expenses}

Although the data above suggest that most elderly live in modest dwellings of adequate quality, it is also necessary to look at the proportion of income devoted to housing expenditures. Analysis of the 1974 Annual Housing Survey by Struyk ${ }^{17}$ found that, in contrast with all households, twice as many elderly headed households were paying an "excessive" (beyond 30 percent) amount of their incomes for housing. Approximately 29 percent of all households headed by a person age 65 or older spent more than 30 percent of their incomes on housing expenditures. Within this category, two subgroups are prominent: about 43 percent of all elderly who live alone and 50 percent of elderly home owners exceed acceptable expense-to-income ratios. Most of these households referenced were concentrated among those with annual incomes of less than $\$ 4,000$ in 1974.

Testimony beforc the U.S. Senate's Special Committee on Aging in 1977 indicated that rising energy prices exacerbate the elderly's housing costs. It was estimated that during 1976, depending on region, lowincome elderly spent 16 to 27 percent of their disposable incomes on energy for their homes. Since then, this has risen. to 30 percent nationally, and projections are that during the 1979-80 winter will climb to 50 percent. ${ }^{18}$ Figure 13, reproduced from data by the Federal Energy

17.R.J. Struyk, "The Housing Expense Burden of Households. Headed by the Elderly," The Gerontologist, 17/5: 447-452, 1977.

18 U.S. Senate, Special Committee on Aging, "Energy Assistance Programs and Pricing Policies in the 50 States," Elderly, Disabled, or LowIncome Households (Washington, DC: U.S. Government Printing Office, 1979). 
FIGURE 13: FUEL COSTS
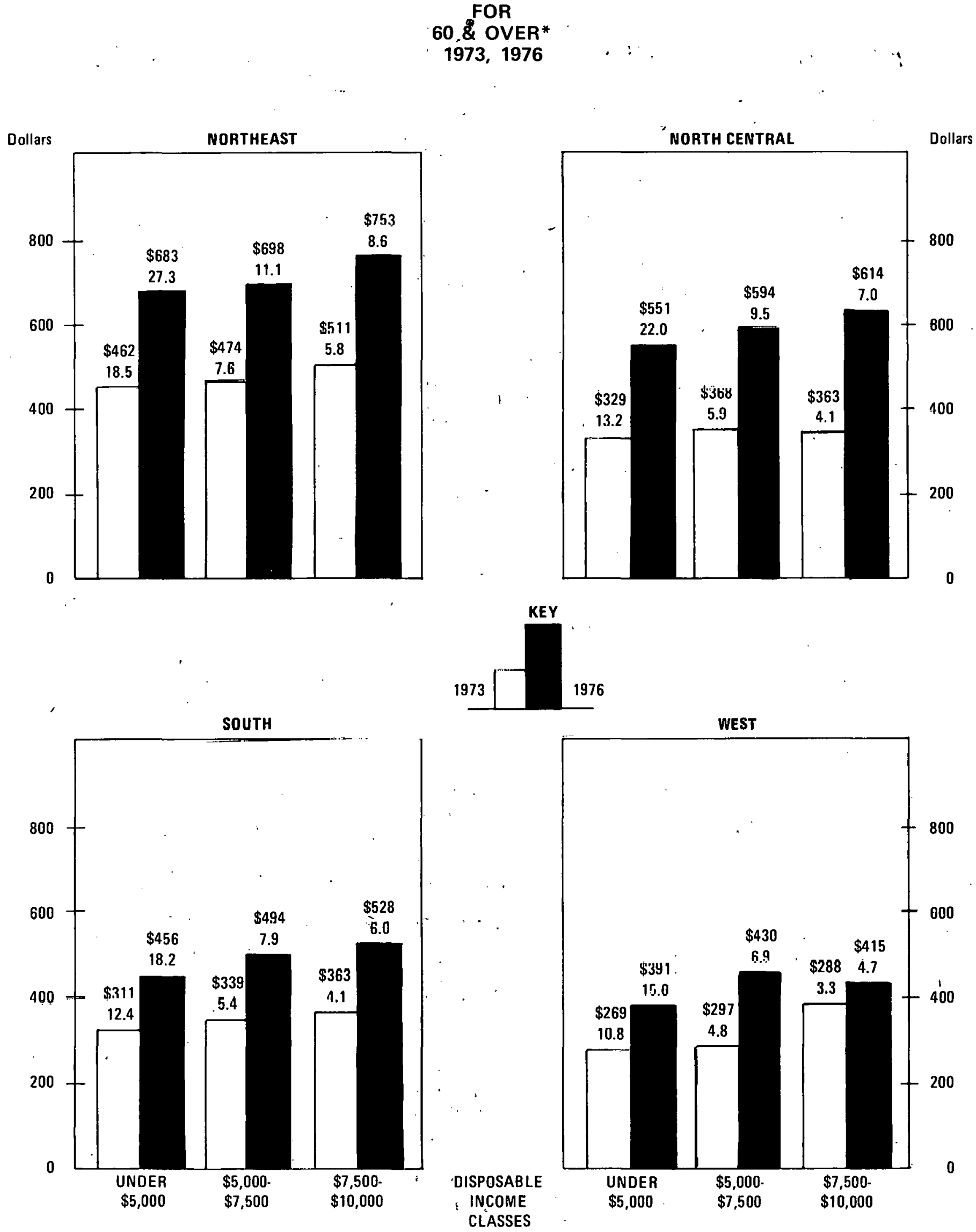

* Corresponding Percentage of Income Shown Below Each Dollar Figure 
Administration, shows the average annual cost of home fuels and percent of income spent on fuel by persons 60 years of age and older in 1973 and 1976. In both dollars expended and percent of income, the energy costs for households in the Northeast and North Central regions exceeded those of the South and West. It should also be noted that, although the higher-income groups spent more for fuel than did the lower-income groups, the cost represented a smaller proportion of their incomes.

Various government programs have been designed to assist the elderly in meeting home-repair, maintenance and energy needs. At least four federal agencies -- Community Services Administration (CAS), Federal Energy Administration (a predecessor of DOE), the Department of Housing and Urban Development, and the Farm and Home Administration -established programs to weatherize homes of the low-income elderly. The efforts seem to have produced few results. Between 1974 and 1977, CAS -- the largest of the four programs -- had weatherized less than 3 percent of the 5.3 million households eligible for the program. ${ }^{19}$

- Other federal agencies offer programs for home repairs or maintenance. The Department of Health, Education and Welfare, under its Title XX program of the Social Security Act, provides federal funding to states for a wide variety of social services. Because each state designs and implements its own service program, comparative analys is of programs is difficult. However, data from HEW for a six-month period in 1976 reveal that less than one percent of the Title XX expenditures was used on housing-improvement services. 20 No information is available on what proportiun of these services was reccived by elderly households.

The Administration on Aging, under Title III of the 01der Americans Act of 1975, also coordinates service programs for the older population. Like the Title XX program, these services are designed and administered at the state and local level. A survey by the United States Conference

19 U.S. Senate, Special Committee on Aging, "The High Cost of Energy," Developments in Aging: 1977, Part I: 41-52. Report No. 95-771 (Washington, DC: U.S. Government Printing Office, 1978).

20 U.S. Department of Health, Education and Welfare, Social services U.S.A., July-September, 1976 (Washingtun, DC: Publication Number (IIDS) 78-02020, 1977). 
of Mayors of 56 cities found that only 12 used Title III funding for home-repair services. ${ }^{2.1}$

An innovative, but largely untested, idea has been to devise a method of assisting the elderly in home maintenance by drawing on the accumulated equity in their homes -- a type of reverse-mortgage system. For the home owners, the equity on their properties frequently represents. a sizeable but inaccessible financial resource. By tapping this asset, without relinquishing occupancy, the elderly person might retain his or her security while diminishing the burden of housing-repair costs.

21 L. MCNickle, Services for the Urban Elderly in Selected cities (Washington, DC: National League of Cities and U.S. Conference Mayors, 1976). 


\section{FACTORS ASSOCIATED WITH ENERGY \\ NEEDS AND ENERGY USAGE OF THE AGED}

The next 20 years will mark a changing United States. First, our previously abundant, non-renewable energy resources will be depleted. This will affect young and old, poor and rich. Second, the years between now and the end of the century will see a rapidly aging population whose citizens will be engaged in a great debate over the advantages and disadvantages of high-technology solutions to economic and social problems. In this debate, energy questions will be at the center of each controversy.

As our non-renewable energy sources become depleted, a shift to alternate energy sources becomes mandatory. Solar energy is an exceedingly strong candidate for the substitution, not only because it is scientifically and pragmatically proven but also because it has gained wide public interest, endorsement and acceptance. In this context, solar energy is particulary attractive for the aged because the group predominantly lives on fixed or limited incomes, provided that suitable arrangements can be made to allow the high initial cost not to be a deterrent.

\section{A. Demographic Background}

The aged -- the so-called "Senior Citizens":-- constitutes an appreciable portion of the U.S. population. If we define Senior Citizens as being those persons above the age of 65 years, we find the following figures:

$\begin{array}{lccc} & \text { SOURCE OF DATA } & \text { NUMBER OF AGED } & \text { PERCENTAGE OF } \\ \text { DATE } & \text { (CENSUS BUREAU) } & \text { IN MILLIONS } & \\ & & & 4.1 \\ 1900 & \text { Actual } & 3.1 & 9.2 \\ 1960 & \text { Actual } & 16.7 & 10.9 \\ 1977 & \text { Actual } & 23.5 & {[10.7-12.5]} \\ 2000 & \text { Projected } & {[31.0]} & {[11.8-17.0]}\end{array}$

Although population projections frequently are not reliable, the above figures for the aged are reasonably accurate because all the aged people counted above are now living. The projected percentages of total 
population are bracketed because future birth rates can only be estimated. However, the only way the aged-population figures could be lower would be by reason of unimaginable causes such as major catastrophies or unbelievable deterioration in health care. These causes would touch not only the elderly population but the younger generations as well.

Clearly, we must meet the energy demands of our Senior Citizens, present and future. It is apparent from the numbers presented that this is not a trifling job but a major undertaking that we, as a benevolent and civilized nation, must face now.

One further demographic peculiarity from our study has become evident, namely, that the future population distribution of the United States will have two lobes: the aged and the very young. This understanding must be factored into the society's energy-usage equation, the ability of consumers to pay energy bills, and the economic burden pursuant to purchase of new equipment related to energy use.

Another related factor is the migration of persons to the Sun Belt States (e.g., Arizona, California, Florida and Texas). There were 3,070,000 net migrations in the United States in 1975. Mnst were migrations to milder climates and/or the Sun.Belt. It is essential, therefore, that we address the question of the aged vis-a-vis solar energy while the latter is still in its infancy, so that we can incorporate the proper incentives and safeguards.

B. Income

On the average, the elderly live on lower incomes. because of the reduction of income that accompanies retirement. For example, in 1974 the median income of families with heads 65 or older was $\$ 7,298$ as compared with the norm of $\$ 12,836$. Thus, it follows that the retired elderly have less disposable money and that energy costs should not take an undue chunk from their monthly pension checks.

There are no reliable, up-to-date statistics about pension and retirement income to predict what is the case in 1979, but there is no doubt that energy costs have risen sharply since 1974. Thus, the retired elderly have been squeezed still further during the last five years. This results in clear discrimination, unintentional as it may be, against the aged as a group in terms of energy usage. 
Relevant to this last point is the fact that, in general, the retired live on relatively fixed incomes. Although some retirement programs have a built-in cost-of-living escalator clause, many do not. (Also, in recent years, the stock market has not been good to the elderly folk who have personally invested in it.) Therefore, rising costs of everything, including energy, punish the fixed-, limited-income elderly, relative to those whose incomes rise automatically with the cost of living.

In addition, solar energy or, in fact, all alternate-energy advocates, must be cognizant of the effect that the high front-end costs for their systems will have on the fixed-and limited-income groups.

\section{Biological and Physical Factors}

Biological and physical factors affect the energy options of the so-called "aged." A person who is not robust can ill afford to fell a tree, chop, cut and carry the logs to a wood-burning stove and/or furnace. Although we know of several men in their seventies who do so, they are exceptions to the rule. (In certain localities in New England, a few socially conscious young people cut extra loads of wood for their elderly neighbors.)

Another biological/physical factor that must be considered in relation to the aged is their sensitivity to extreme, temperatures. Thus, if temperatures are kept too low, hypothermia may result. On the other hand, if temperatures rise too high, there is danger of hyperpyrexia. Either could be fatal, and safeguards against extreme temperatures are essential.

Another biophysical factor that affects the elderly is the loss of visual acuity. This means that the elderly must have proper lighting to read, do their chores, and move about without stumbling over obstructions. Healing of broken limbs or hips due to a fall on an ill-lighted step or staircase can be particularly painful and incapacitating for the elderly for whom a prolonged healing period frequently results in pronounced psychological depression. The elderly need cheap, reliable energy around-the-clock.

D. Housing

The present elderiy live primarily in homes built prior to the 
1940's, many of which are located in urban areas or in the central city. Retrofitting them with renewable-energy systems is not simple. However, there is a pronounced move to the suburbs by those who soon will be in the elderly category. Suburban homes are more amenable to retrofitting because they are better-built and frequently are detached structures.

If we consider that there are some 72 million housing units in the United States, less than 1.5 million of which are built each year (most of these by young homeowners), it stands to reason that one solution to the energy needs of elderly and will-be-elderly is to bring about a massive program of retrofitting. This is not only technologically difficult, but it would he extremely: costly. Therefore, it might be considered that the Department of Energy and the Department of Housing and Urban Development to join forces with savings and loan associations, as well as with mortgage banks, in order to make it financjally easy for the elderly to retrofit their homes with renewable energy systems. The pronounced movement of retirees (the elderly of the future) to the South and West -- where sunshine is more abundantly available than in other sections of the country -- may make such retrofitting less difficult than it seems.

The elderly, contrary to popular opinion, do not move much and generally stay in the homes they purchased years ago. To provide them with cheap and reliable energy means a massive program of retrofitting, in which the problems are compounded because the elderly do not necessarily congregate in low-energy-cost locales.

\section{E. Miscellaneous Factors}

The elderly are less likely to choose decentralized or "small is beautiful" energy systems. If they have decentralized systems, they will be physically limited in repairing these systems, and certainly there will be anxlety related to the costs of calling a repairman. A centralized system would mean that the utility company sends out a serviceman, generally at no extra cost.

Contrary to popular opinion, many of the elderly are visionary and like to be where the action is. In at least one retirement home the residents are installing solar energy because they like to be in the forefront while not facing increasing energy costs. They do not mind 
taking judicious risks even though the front-end cost may be high.

Innumerable professional contacts with the elderly as individuals and in groups tend to bring out this point, repeatedly. The elderly do not feel that they deserve the "old and stodgy" stereotype -- perhaps old -but they feel a need for one more chance to serve society in the few years they have remaining by influencing the society toward making bold changes in which they believe. 


\section{CONCLUSIONS}

The elderly are a unique constituency sharing certain characteristics of the poor and handicapped. They are a reasonably articulate group, which will exert well-informed pressure for what they consider to be the needs of their group and the nation as a whole. They are extremely concerned about the energy problem, largely because of their medical and economic vulnerability. The combination of a weakening physical constitution; lower than average income; generally older, less energy-efficient housing; living mostly in the city and, to a significant extent, nearly alone or r.nmpletely alone licads to the conclusion that needs of this substantial, growing segment of our society must be affurded consideration as the social assessments of our alternative energy systems are proposed and developed. The following conclusionary remarks are supportive of this premise.

1. The absolute number of aged will increase markedly between 1979 and 2020, particularly as the baby-boom children. of the 1950's reach 65 . Their percentage of the population is undetermined; however, because the birth rate between now and 2020 cannot be predicted accurately.

2. The percentage of the aged will remain substantially constant but sufficiently high to cause the United States to be called an "aging nation."

3. Most aged reside in homes in which they have been living for several years. Accordingly, their homes are not completely energyefficient and require retrofitting for alternate-energy systems. In terms of number of housing units, $7.3 \%$ would be directly suitable for electric energy supplied by utilities as generated by any centralized electric power system. An undetermined fraction of the rest of the homes could be retrofitted to electric heating and cooling (energy generated by these centralized systems and supplied as above). Because this depends on the type of heating and cooling and the age of the home, the number is undetermined -- but it should be substantial.

4. Although there is a recent tendency of the aged to migrate to Sun Belt States, conclusions cannot be made wholly based on this fact because a majority of the elderly remain in their original homes or do 
not move from those locales. Alternate-energy installations for the aged will more than likely be retrofitted rather than new.

5. Considering new homes that the aged may occupy (probably in Sun Belt States), the technology of solar water heating is well established. However, in these states cheap, reliable cooling is also desirable to prevent hyperpyrexia. Here, the feasibility of centralized electric power has to be measured vis-a-vis photovoltaics, as well as other solar energy forms such as wind energy generation.

6. The number of aged presently living and predicted in the future (2000-2020) suggests that there are subtle problems pertaining to energy and the aged that must be taken into consideration in developing any future national or regional energy plan.

The elderly are; and will continue to be, subsidized by society as a whole. There is heated discussion within the institutions of our society over the forms to be utilized for this subsidy. In the case of energy, it is argued that the "food versus heat" choice should not have to be made by the elderly and that direct subsidies such as food and energy stamps should be used. Others" argue that direct energy subsidization to any segment frustrates the conservation goal by making it easier for a disadvantaged consumer to waste energy. However, in any case, it seems clear that the features of a system which would best serve the elderly are as follows:

1. Low-cost to the individual elderly person whether because of the system itself or because of a general subsidy to disadvantaged or because of a specific government subsidy for the specific energy system;

2. Reliable, to avoid the potential disaster to the elderly from, first, a failure to sense an outage and then the inability to withstand the consequences of an outage;

3. Low-maintenance and ease of operation. The elderly tend to have less physical capability and less inclination to perform maintenance or operation functions which are either physically or mentally demanding.

In short, to paraphrase a woman participant at a workshop leading to this report of what the elderly want and probably need, "I want any system which I can afford which is as easy to use as a light switch and which I don't have to worry about at ail1." 


\section{REFERENCES}

Brotman, H.B. "The Economics of Aging." Paper presented at the Conference on Aging. University of Miami; Coral Gables, Florida, 1974.

Long, L.H. and K.A. Hansen: "Reasons for Interstate Migration: Jobs, Retirement, Climate, and Other Influences." Paper presented at the Southern Regional Demographic Group. San Antonio, Texas, 1978.

Lopata, H.Z. Widowhood in an American City. Cambridge, Massachusetts: Sahenkman Preșs, 1971.

McNickle, L. Services for the Urban Elderly in Selected cities. Washington, D.C.: National League of Cities and U.S. Conference Mayors, 1976.

Morris, W. (ed). The American Heritage Dictionary of the Enqlish Language. New York: American Heritage Publishing Company, 1969.

Portnoi, V. "Uverview of Aging as a Bio-psycho-social Process." Unpublished; January 1979.

Shanas, E.; P. Townsend; D. Wedderburn; H. Frifs; P. Milhoj; and J. Stewhouwer. old People in Three Industrial Societies. New York: Athertun Press, 1968.

SiegeT, J.S. "Demographic Aspects of Aging and the 0lder Population in the United States." Current Population Reports. Series P-23, No. 59. Washington, D.C.: U.S. Government Printing Office, 1976.

Soldo, B.J. The Determinants of Temporal Variations in Living Arrangements Among the Elderly: 1960-1970. Unpublished Ph.D. dissertation. Duke University, 1977.

Soldo, B.J. and C.J. DeVita. "Profiles of Black Aged." Paper presented at the Conference on Blacks and Retirement: An Untapped Natiunal Resource; sponsored by the Council on Minority Planning and Strategy. Washington, D.C., 1978.

Soldo, B.J. and P. Lauriat. "Living Arrangements Among the Elderly in the United States: A Log-Linear Approach." Journal of Comparative Family Studies: $\underline{7}, 1976$.

Struyk, R.J. "The Housing Expense Burden of Households Headed by the Elderly." The Gerontologist: 17/5, 1977.

Struyk, R.J. "The Housing Situation of Elderly Americans." The Gerontologist: $17 / 2,1977$.

U.S. Bureau of the Census. "Social and Economic Characteristics of the Metropolitan and Nonmetropolitan Population: 1977 and 1970." Current Population Reports. Series P-23, No. 75. Washington, D.C.: U.S. Government Printing Office, 1978. 
U.S. Department of Health, Education and Welfare. Social Services U.S.A. July-September, 1976. Washington, D.C.: Publication No. (HDS) 78$02020,1977$.

U.S. Senate, Special Committee on Aging. "Energy Assistance Programs and Pricing Policies in the 50 States." Elderly, Disasbled, or Low-Income Households. Washington, D.C.: U.S. Government Printing Office, 1979.

U.S. Senate, Special Committee on Aging. "The High Cost of Energy." "Developments in Aging: 1977, Part I. Report No. 95-771. Washington, D.C.: U.S. Government Printing Office, 1978. 
UNITED STATES

DEPARTMENT OF ENERGY

WASHINGTON, D.C. 20585

OFFICIAL BUSINESS

PENALTY FOR PRIVATE USE, $\$ 300$
POSTAGE AND FEES PAID U.S. DEPARTMENT OF ENERGY DOE 360 